Elsevier Editorial System(tm) for North American Journal of Economics and Finance Manuscript Draft

Manuscript Number: NAJEF-D-14-00041R2

Title: An update on EMU sovereign yield spread drivers in times of crisis: A panel data analysis

Article Type: Full Length Article

Keywords: Sovereign bond spreads, Panel data, Eurozone

Corresponding Author: Dr. Simon Sosvilla-Rivero, Ph D in Economics

Corresponding Author's Institution: Universidad Complutense de Madrid

First Author: Marta Gomez-Puig, Ph D in Economics

Order of Authors: Marta Gomez-Puig, Ph D in Economics; Simon Sosvilla-Rivero, Ph D in Economics; María del Carmen Ramos-Herrera

Abstract: We empirically investigate the determinants of EMU sovereign bond yield spreads with respect to the German bund. Using panel data techniques, we examine the role of a wide set of potential drivers. To our knowledge, this paper presents one of the most exhaustive compilations of the variables used in the literature to study the behaviour of sovereign yield spreads and, in particular, to gauge the effect on these spreads of changes in market sentiment and risk aversion. We use a sample of both central and peripheral countries from January 1999 to December 2012 and assess whether there were significant changes after the outbreak of the euro area debt crisis. Our results suggest that the rise in sovereign risk in central countries can only be partially explained by the evolution of local macroeconomic variables in those countries. Besides, without exception, the marginal effects of sovereign spread drivers (specifically, the variables that measure global market sentiment) increased during the crisis compared to the pre-crisis period, especially in peripheral countries. Moreover, the increase in the significance of the banking level of indebtedness and foreign bank's claims in the public sector (mainly in peripheral countries) along with the crisis unfolding seems to highlight the interconnection between private and public debt and thus, between banking and sovereign crises. 
Prof. Hamid Beladi

Editor

North American Journal of Economics and Finance

Madrid, 17 September 2014

Ref. No.: NAJEF-D-14-00041R1

Dear Professor Beladi,

Thank you very much for accepting for publication the revised version of our paper. Please find enclosed a copy of the revised version of the paper " An update on EMU sovereign yield spread drivers in times of crisis: A panel data analysis " (jointly written with Marta Gómez-Puig and Maria del Carmen Ramos-Herrera).

Following your instructions, we have put our manuscript in the format that is required for publication.

Yours sincerely,

Simon Sosvilla-Rivero 


\title{
AN UPDATE ON EMU SOVEREIGN YIELD SPREAD DRIVERS IN TIMES OF CRISIS: A PANEL DATA ANALYSIS*
}

\author{
Marta Gómez-Puig ${ }^{a}$, Simón Sosvilla-Rivero ${ }^{\mathrm{b}}$, María del Carmen Ramos-Herrera ${ }^{\mathrm{b}}$ \\ ${ }^{a}$ Department of Economic Theory, Universitat de Barcelona. 08034 Barcelona, Spain \\ ${ }^{b}$ Department of Quantitative Economics, Universidad Complutense de Madrid. 28223 \\ Madrid, Spain
}

\begin{abstract}
We empirically investigate the determinants of EMU sovereign bond yield spreads with respect to the German bund. Using panel data techniques, we examine the role of a wide set of potential drivers. To our knowledge, this paper presents one of the most exhaustive compilations of the variables used in the literature to study the behaviour of sovereign yield spreads and, in particular, to gauge the effect on these spreads of changes in market sentiment and risk aversion. We use a sample of both central and peripheral countries from January 1999 to December 2012 and assess whether there were significant changes after the outbreak of the euro area debt crisis. Our results suggest that the rise in sovereign risk in central countries can only be partially explained by the evolution of local macroeconomic variables in those countries. Besides, without exception, the marginal effects of sovereign spread drivers (specifically, the variables that measure global market sentiment) increased during the crisis compared to the pre-crisis period, especially in peripheral countries. Moreover, the increase in the significance of the banking level of indebtedness and foreign bank's claims in the public sector (mainly in peripheral countries) along with the crisis unfolding seems to highlight the interconnection between private and public debt and thus, between banking and sovereign crises.
\end{abstract}

Keywords: Sovereign bond spreads, Panel data, Eurozone.

JEL Classification Codes: C33, C52, E44, F36, G15

\footnotetext{
* aDepartment of Economic Theory, Universitat de Barcelona, Av. Diagonal 696, 08034 Barcelona, Spain. E-mail: marta.gomezpuig@ub.edu. b,c Department of Quantitative Economics, Universidad Complutense de Madrid, Campus de Somosaguas, 28223 Madrid, Spain. E-mail: madelram@ccee.ucm.es, sosvilla@ccee.ucm.es. Corresponding author: Simón Sosvilla-Rivero, Department of Quantitative Economics, Universidad Complutense de Madrid, 28223 Madrid, Spain. T: +34-913 942 342. Fax: +34- 913942591.
} 
An update on EMU sovereign yield spread drivers in times of crisis: A panel data analysis

\section{Highlights}

- We examine EMU sovereign bond yield spreads drivers using panel data techniques

- We use a broad set of fundamentals, market sentiment and risk aversion variables

- Sovereign risk in central countries is mainly related to regional fundamentals

- Market sentiment and investors' risk aversion are relevant for peripheral countries

- The marginal effects of sovereign spread drivers increased during the crisis 


\section{*Detailed Response to Reviewers}

As can be seen in the decision letter, in the revised version we have adequately addresses the concerns of the referees and the paper have been accepted for publication in the North American Journal of Economics and Finance.

In the accepted, revised version we had made the appropriate connections with two relevant papers published in The North American Journal of Economics and Finance within the last two years.

We thank the referee and the editor for their comments and suggestions that greatly improved the quality of the final version of the paper. 


\title{
AN UPDATE ON EMU SOVEREIGN YIELD SPREAD DRIVERS IN TIMES OF CRISIS: A PANEL DATA ANALYSIS
}

\begin{abstract}
We empirically investigate the determinants of EMU sovereign bond yield spreads with respect to the German bund. Using panel data techniques, we examine the role of a wide set of potential drivers. To our knowledge, this paper presents one of the most exhaustive compilations of the variables used in the literature to study the behaviour of sovereign yield spreads and, in particular, to gauge the effect on these spreads of changes in market sentiment and risk aversion. We use a sample of both central and peripheral countries from January 1999 to December 2012 and assess whether there were significant changes after the outbreak of the euro area debt crisis. Our results suggest that the rise in sovereign risk in central countries can only be partially explained by the evolution of local macroeconomic variables in those countries. Besides, without exception, the marginal effects of sovereign spread drivers (specifically, the variables that measure global market sentiment) increased during the crisis compared to the pre-crisis period, especially in peripheral countries. Moreover, the increase in the significance of the banking level of indebtedness and foreign bank's claims in the public sector (mainly in peripheral countries) along with the crisis unfolding seems to highlight the interconnection between private and public debt and thus, between banking and sovereign crises.
\end{abstract}

Keywords: Sovereign bond spreads, Panel data, Eurozone.

JEL Classification Codes: C33, C52, E44, F36, G15 


\section{Introduction}

The recent European sovereign debt crisis has spurred academics and policy makers to try to identify the drivers of sovereign risk, in order to be able to react to similar challenges in the future. Figure 1 shows that from the start of the European Economic and Monetary Union (EMU) and before the financial crisis, spreads on 10-year sovereign bond yields relative to the German benchmark moved in a narrow range with only very slight differences across countries. Nevertheless, with the financial crisis the picture changed completely; after the outbreak of the Greek sovereign debt crisis in late 2009, sovereign risk differentials rose sharply and then continued to fluctuate strongly. Indeed, the financial crisis put the spotlight on the macroeconomic and fiscal imbalances within EMU countries which had largely been ignored during the period of stability ${ }^{1}$ when the markets had seemed to underestimate the possibility that governments might default.

These events raised some important questions for economists. What explains the disparities and the shift in the pricing of sovereign debt risk during the crisis period? Have the drivers of yield spreads and their relevance changed since the crisis? Are there important differences between peripheral and central countries?

Euro area sovereign bond markets initially attracted attention from academia as a way to assess the impact of the EMU on the process of financial integration [see Codogno et al. (2003), Baele et al. (2004), or Gómez-Puig (2006 and 2008), to name a few]. In these first studies, the standard definition of sovereign risk included its two main domestic components, market liquidity and credit risk, and an international risk factor which reflected investors' risk aversion. Some of the research then focused on the analysis of the relative importance of systemic versus idiosyncratic risk factors in explaining yield spreads in Europe after the introduction of the common currency, even though the empirical evidence was not conclusive. Several studies [Geyer et al. (2004) and Pagano and Von Thadden (2004), among others] stressed the importance of systemic risk in the behaviour of yield differentials in EMU countries, while others showed that the idiosyncratic risk component in the movements of spreads was greater than the systemic risk [e.g., GomézPuig (2009), Dötz and Fischer (2010) and Favero and Missale (2012)]. All in all, studies whose data end before the global financial crisis coincided in stating that euro area bond markets shared a high degree of financial integration (see, e.g., Abad et al., 2010).

${ }^{1}$ Kocenda et al. (2008) empirically examine the fiscal convergence of the European Union members and their results suggest that monetary unions do not necessarily encourage fiscal convergence for its members. 
However, the sovereign debt crisis in Europe which began in late 2009 has revived the literature on euro area sovereign spread drivers and has attributed increasing importance to uncertainty and variables reflecting investment confidence conditions and perceptions for the upcoming economic activity (see, e.g. Georgoutsos and Migiakis, 2013). In this regard, Gómez-Puig and Sosvilla-Rivero (2014a) ${ }^{2}$ point out that a crisis in one country may give a "wake-up call" to international investors to reassess the risks in other countries; since uninformed or less informed investors that may have difficulty in extracting the signals from the falling prices, in following the strategies of better informed investors, may generate excess co-movements across the markets ${ }^{3}$. Likewise, Favero and Missale (2012) find that the credit risk component has increased in importance as a determinant of sovereign bond spreads because of the adverse market sentiment conditions after the global financial crisis. Similar arguments can be found in other recent studies using data that extend beyond the crisis period [see, among others, Palladini and Portes (2011), Beirne and Fratzscher (2013) or Aizenman et al., (2013)]. Besides, many authors have stressed the importance of other fundamental variables beyond the country's fiscal position to explain yield spread behaviour after the outbreak of the crisis [Mody (2009), Barrios et al. (2009), the IMF (2010), Bolton and Jeanne (2011), Allen et al. (2011) and Acharya et al. (2014), to name a few]. In addition, comparing these findings to the ones with data samples ending before the crisis period provides evidence of potential in-sample changes in the specification of the spreads. For instance, several studies have highlighted other determinants, such as the dynamic properties of sovereign spreads over time [see, e.g., Pozzi and Wolswijk (2008), Gerlach et al. (2010), A 3 mann and Boysen-Hogrefe (2012) and Bernoth and Erdogan (2012)].

In this framework, the contribution of this paper to the existing literature is threefold. The first is methodological: we adopt an eclectic approach, using a general-to-specific modelling strategy with panel data techniques, to empirically assess the relevance of the variables that have been proposed in the recent theoretical and empirical literature as potential drivers of EMU sovereign bond yield spreads. We provide an updated review of the literature on the determinants of sovereign bond spreads and compile a comprehensive data base (see

\footnotetext{
In this paper, the authors analyse contagion using an approach that is based on the channels of transmission that are used to spread the effects of the crisis [(Masson, 1999) and Kaminsky and Reinhart (2000) among others]. Specifically, they examine whether the transmission of the recent crisis in euro area sovereign debt markets was due to "fundamentalsbased" or "pure contagion". Their results suggest the importance of both variables proxying market sentiment and macrofundamentals in determining contagion and underline the coexistence of "pure contagion" and "fundamentalsbased contagion" during the recent European debt crisis.

3 The degree of non-anticipation of a crisis by investors or sudden shifts in market confidence and expectations have been identified as important factors causing “pure contagion” (see Masson, 1999 and Mondria and Quintana-Domeque, 2013).
} 
Section 3) with potential drivers including not only variables that measure macroeconomic fundamentals (at both local and regional level) and banking linkages, but also those that capture changes in market sentiment: either idiosyncratic, regional or global. To our knowledge, this paper presents one of the most exhaustive compilations of the variables used in the literature to examine sovereign yield spread behaviour and, in particular, to gauge the effect on yield spreads of changes in market sentiment and risk aversion, whose importance has been particularly stressed by the literature since the outbreak of the recent debt crisis. The second contribution has to do with the political relevance of the sample examined, i.e. both central (Austria, Belgium, Finland, France and The Netherlands) ${ }^{4}$ and peripheral (Greece, Ireland, Italy, Portugal and Spain) countries from January 1999 to December 2012. This focus allows us to disentangle possible differences in the behaviour between these two groups of countries within the EMU. Lastly, following the literature that re-emerged with the euro area sovereign debt crisis, the third contribution is the analysis of the time-varying pricing differences of the same spread drivers by market participants since the crisis outbreak. As explained above, in recent years, many authors have applied a variety of methodologies to focus on this topic [Gerlach et al. (2010), Bernoth and Erdogan (2012) or Georgoutsos and Migiakis (2013) to name a few]. So, this paper aims to present an updated analysis of sovereign yield spread drivers in times of crisis.

The rest of the paper is organized as follows. The econometric methodology is explained in Section 2. The dataset used to analyse sovereign spreads determinants is described in Section 3. Section 4 presents the empirical findings, whilst Section 5 offers some concluding remarks.

\section{Econometric Methodology}

As mentioned in the Introduction, we adopt an eclectic approach and apply a general-tospecific modelling strategy to empirically evaluate the relevance of the highest number of variables that have been proposed in the recent theoretical and empirical literature as potential drivers of EMU sovereign bond yield spreads. To this end, a general unrestricted model is formulated to provide a consistent approximation to the "local" data generation process (namely, the joint distribution of the subset of variables under analysis), given the previous theoretical and empirical background. The empirical analysis commences from this general specification and is then tested for mis-specifications; if none are apparent, it is

\footnotetext{
${ }^{4}$ This classification between EMU central and peripheral countries follows the standard division presented in the
} literature. 
simplified to a parsimonious, consistent representation, each simplification step being checked by diagnostic testing.

Given the relatively short sample available since the introduction of the euro in 1999, we use panel data econometrics to combine the power of cross section averaging with all the subtleties of temporal dependence (see Baltagi, 2008). An analysis of the advantages and limitations of using panel data sets is presented by Hsiao (2003). The main advantages over single cross-sections or time series data are the following: a) more accurate inference of model parameters, b) greater capacity for capturing the complexity of economic relationships, c) more informative results, d) more ability to control for individual unobserved heterogeneity, and e) its simpler computation and statistical inference. Indeed, this methodology has already been used in the literature to examine EMU sovereign spread determinants [see, e.g. Schuknecht et al. (2009), Von Hagen et al. (2011) or Gómez-Puig (2006 and 2008)].

Our data set consists of a large number of variables that are observed in a sequence of successive moments in time forming a data panel.

\section{Data}

The dependent variables in our empirical analysis are bond yield spreads, derived as differences between 10-year sovereign bond yields of EMU-founding countries along with Greece and yields of the equivalent German bund. Therefore, our sample contains both central (Austria, Belgium, Finland, France and the Netherlands) and peripheral EMU countries (Greece, Ireland, Italy, Portugal and Spain).

We use monthly data from January 1999 to December 2012 collected from Thomson Reuters Datastream. Figure 1 plots the evolution of daily 10-year sovereign bond spreads for each country in our sample. A simple look at this figure indicates the differences in the yield behaviour before and after the outbreak of the Greek sovereign debt crisis at the end of 2009.

[nsert Figure 1 here]

\footnotetext{
${ }^{5}$ Luxembourg is excluded from the present analysis, because of its very low level of outstanding amount of sovereign bonds.
} 
Specifically, it is striking that between the introduction of the euro in January 1999 and November 2009, when it became clear that the Greek economy was unable to finance its sovereign debt, spreads on bonds of EMU countries moved in a narrow range with only slight differentiation across countries. In fact, the stability and convergence of spreads was considered a hallmark of successful financial integration (see, e.g. Abad et. al., 2010) inside the euro area (neither the subprime crisis nor the collapse of Lehman Brothers bit significantly into euro sovereign spreads).

Nevertheless, once the global financial crisis began to affect the real sector, the imbalances within euro area countries were plain to see. Spreads, which had reached levels close to zero between the launch of the euro and October 2009 (the average value of the 10-year yield spread against the German bund moved between 10 and 47 basis points in the cases of France and Greece respectively), have risen ever since. Indeed, the risk premium on EMU government bonds increased strongly from November 2009, reflecting investor perceptions of upcoming risks. Figure 1 shows that by late 2011 and early 2012 it reached maximum levels of 4680 basis points in Greece, 1141 in Portugal, 1125 in Ireland, 635 in Spain and 550 in Italy. This widespread increase in sovereign spreads meant that certain euro area Member States were under enormous pressure to finance their debt, and funding costs rose significantly; this led to an increase in rollover risk as debt had to be refinanced at unusually high costs and, in extreme cases, could not be rolled over at all, triggering the need for a rescue (see Caceres et. al., 2010).

With regard to the independent variables, as explained in the Introduction, we include variables that measure macroeconomic fundamentals beyond the country's fiscal position (at both the local and regional level), some potential financial channels of crisis transmission, and variables that may capture changes in market sentiment: either idiosyncratic, regional or global. A summary with the definitions and sources of all the explanatory variables used in the panel models is presented in Appendix A. All the variables included in the estimation that capture both macroeconomic fundamentals or financial linkages are in relative terms to the German ones, as our dependent variable is the difference between the 10-year sovereign yield of each country over Germany.

Specifically, according to Dornbusch et al. (2000), reasons that may explain the evolution of sovereign yields spreads can be divided into two groups: fundamentals-based reasons on 
the one hand, and investor behaviour-based reasons on the other. While the former works through real and financial linkages across countries, the latter is more sentiment-driven. Following the literature, in order to measure the impact of fundamental variables (at both local and regional level) on sovereign spread behaviour, we use instruments that gauge not only each country's fiscal position, but the market liquidity in each country, its foreign debt, its potential rate of growth, and the loss of competitiveness as well. The private sector level of indebtedness has been added in the analysis of the effect of local fundamental variables and, finally, we have included foreign claims on sectoral private debt and cross-border banking system linkages as measures of the degree of crisis transmission through the financial system (see Gómez-Puig and Sosvilla-Rivero, 2013).

In particular, the variables used to measure the country's fiscal position are the government debt-to-GDP and the government deficit-to-GDP. These two variables have been widely used in the literature by other authors (see, e.g., Bayoumi et al., 1995) and present an advantage over credit rating in that they cannot be considered ex post measures of fiscal sustainability. Since they are measures of credit risk, they should be directly related with sovereign spreads increase.

Regarding the liquidity premium in each sovereign debt market, empirical papers examining the influence of market liquidity in bond markets use a variety of measures to gauge its three main dimensions of tightness, depth and resiliency ${ }^{6}$. However, since several studies have shown that all liquidity measures are closely related to each other, we chose the overall outstanding volume of sovereign $\operatorname{debt}^{7}$ as a proxy of liquidity differences between markets. Since liquidity premium decreases with market size, we would expect this variable to have a negative effect on sovereign spreads.

Besides, the current-account-balance-to-GDP ratio is the instrument used as a proxy of the foreign debt and the net position of the country vis-à-vis the rest of the world. Note that this variable is defined as the difference between exports and imports. Therefore, an increase would signal an improvement in the net position of the country towards the rest of the world, reducing sovereign spreads. The importance of this variable has been

\footnotetext{
${ }^{6}$ These measures include trading volume, bid-ask spreads, the outstanding amount of debt securities, and the issue size of the specific bond. Many authors [Gómez-Puig (2006), Korajczyk and Sadka (2008), and Gerlach et al. (2010), to name a few], have presented empirical evidence which supports the high linkages between all liquidity measures.

7 It is considered a measure of market depth because larger markets may present lower information costs as their securities are likely to trade frequently, and a relatively large number of investors may own or may have analysed their features
} 
underlined by the IMF (2010) and Barrios et al. (2009). In view of Mody (2009)'s argument that countries' sensitivity to the financial crisis is more pronounced the greater the loss of their growth potential and competitiveness, we include instruments that measure these features. The unemployment rate is the variable used to capture the country's growth potential, whilst the Harmonized Index of Consumer Prices monthly interannual rate of growth is the inflation rate measure that we use as a proxy of the appreciation of the real exchange rate and, thus, the country's loss of competitiveness. An increase in either unemployment or inflation represents a deterioration of growth potential and competitiveness; therefore, it should augment sovereign spreads.

To assess the role of private debt in the euro area sovereign debt crisis, we also incorporate instruments that capture the level of indebtedness of each country's private sector in the analysis. ${ }^{8}$ To this end, we make use of a single dataset on private debt-to-GDP by sector in each EMU country. In particular, we apply three variables: banks' debt-to-GDP, nonfinancial corporations' debt-to-GDP, and households' debt-to-GDP, constructed with data obtained from the European Central Bank Statistics. Since high leverage levels in the private sector have a negative impact on the public sector's sustainability, an increase in these three variables would positively affect sovereign yield spreads?

Finally, according to certain authors [Bolton and Jeanne (2011) and Allen et al. (2011), among them], in a scenario of increased international financial activity in the euro area, not only are public finance imbalances key determinants of the probability that the sovereign debt crisis could spill over from one country to another, but the transmission of the crisis through the banking system may also be a major issue. As a result, in our analysis we also include variables that capture the important cross-border banking system linkages in euro area countries. These linkages are measured using the consolidated claims on an immediate borrower basis of Bank for International Settlements (BIS) reporting banks in the public, banking and non-financial private sectors as a proportion of GDP. Moreover, we also explore the role of consolidated claims on an immediate borrower basis, provided by BIS by nationality of reporting banks as a proportion of total foreign claims on each country.

\footnotetext{
8 The interconnection between private and public debt and thus, between banking and sovereign crises is obvious. However, whether it was private debt which ultimately bankrupted sovereigns or if, conversely, excessive public debt undermined the banking sector is a question that is not easily answered. Indeed, the main causes of the debt crises in Europe vary according to the country. In some countries, the public sector was overwhelmed by the costs of cleaning up the banking system and forced to seek bail-outs (Ireland and Spain); whilst in others, the main source of vulnerability was certainly concentrated on the public sector balance sheet itself (Greece, Portugal and Italy, for instance).

9 The recent literature has focused on the interdependencies that exist between the banking and the sovereign sector [see Brunnemeier et al. (2011), Reichlin (2013)].
} 
We expect that higher banking sector exposure and cross-border banking system linkages will be associated with an increase in sovereign spreads ${ }^{10}$.

Four variables have been used to gauge the effect of regional, global or local market sentiment in each different country over sovereign spreads: stock returns, stock volatility, an index of economic policy uncertainty, and an index of the fiscal stance.

Monthly stock returns are used in order to reflect portfolio allocation effects between stocks and bonds in each country (see, among others, Aizenman et al., 2013 and Georgoutsos and Migiakis, 2013). Since periods of financial turmoil and negative stock returns may be accompanied by rises in sovereign bond spreads because of an increased propensity to hold safer assets (the German bund in our case), we expect a negative association between them. To this end, differences in logged stock index prices of the last and the first day of the month have been calculated for the benchmark stock index in each country; whilst the Eurostoxx-50 and the Standard and Poor's 500 have been used to calculate the evolution of regional and global stock returns respectively. Volatility is a measure of the level of uncertainty prevailing in stock markets ${ }^{11}$. In this paper implied volatility has been used to gauge both regional and global stock market volatility. In particular, the variables VSTOXX and VIX, which measure implied volatility in Eurostoxx50 and Standard and Poor's 500 index options and have been widely used in the literature by other authors (see, e.g., Afonso, 2012, Aizenman et al., 2013, and Battistini et al., 2013) as measures of uncertainty in the Eurozone and the global financial markets respectively. However, since implied volatility indices were not available for all countries, we opted for the monthly standard deviation of equity returns in each country to capture local stock market volatility. The increased stock market volatility is usually accompanied by an increase in other risk components and, thus, leads to increases in bond yield spreads; as a result, we expect a positive sign for the respective coefficient.

Some authors (see, e.g. Ades and Chua, 1993) find that political instability has strong negative effects on a country's per capita growth rate. Thus, to assess whether policy uncertainty has an influence on the decisions of bond market investors, we have used the index of economic policy uncertainty (EPU), built by Baker et al. (2013), which draws on

\footnotetext{
10 The construction and evolution of sectoral private debt, foreign banks claims by sector and by nationality of reporting banks are explained in Gómez-Puig and Sosvilla-Rivero (2013).

11 Two different approaches are used to estimate it; while historical volatility involves measuring the standard deviation of closing returns for any particular security over a given period of time, implied volatility is derived from option prices. The latter represents the estimates and assumptions of market participants involved in a trade, on the basis of a given option price, and has been used to gauge both regional and global stock market volatility
} 
the frequency of newspaper references to policy uncertainty and other indicators and is available for Germany, France, Italy, Spain, Europe and the United States. A positive sign is also expected for the respective coefficient since policy uncertainty may discourage investments in sovereign debt markets. A related question is the analysis of the impact of the fiscal stance of each country on sovereign debt spreads. Therefore, the index of the fiscal stance suggested by Polito and Wickens $(2011,2012)$ is also included in the analysis. Unlike the standard econometric tests of fiscal sustainability, this index is suitable for assessing fiscal policy in the short and medium term as it can measure the fiscal consolidation needed to achieve a pre-specified debt target at any future time horizon. To capture regional and global risk we have used the European and United States indices of fiscal stance respectively. Since by construction the higher the index; the worse the fiscal stance, we expect a positive sign for its coefficient.

Another variable, the consumer confidence indicator ${ }^{12}$, has been used to measure either regional (Eurozone) or local market sentiment in each different country. This index is used to gauge economic agents' perceptions of future economic activity. It seems reasonable to expect a negative relationship between it and spreads, since an increase in consumer confidence may lead to a rise in investor confidence in the economy's potential for growth. Finally, the analysis of the influence of local, regional and global market sentiment on sovereign yield spreads has been completed by the inclusion of one more variable in the first case, five additional variables in the second, and two supplementary variables in the third.

The credit rating has been included as a proxy of the market perception of default risk in each local market ${ }^{13}$. The five variables that have been added to explore the impact of regional market sentiment on sovereign spreads are the following. Firstly, following Georgoutsos and Migiakis (2013), two variables have been included in order to account for the effects of the prevailing credit risk conditions in the European corporate bond market

\footnotetext{
12 According to some authors (see, e.g., Rua, 2002), the Economic Sentiment Indicator (ESI) has informative content for the GDP growth rate and can therefore be used to gauge economic agents' perceptions of future economic activity. However, since this indicator was not available for Ireland, and the correlation between the Consumer Confidence Indicator (CCI) and the ESI is very high, we decided to include the CCI in the analysis.

13 Following Blanco (2001), we built a monthly scale to estimate the effect of investor sentiment based on the rating offered by the three most important agencies (Standard \&Poor's, Moody's and Fitch). Since this variable is considered an ex post measure of fiscal sustainability it should have a positive impact on sovereign spreads (by construction, the higher the scale; the worse the rating categories).
} 
(EuroCSPREAD, EuroITRAXX -both in the financial and in the non-financial sector-). ${ }^{14}$ Considering the "safe haven" status of the German bund, we expect these two variables, which measure credit risk in the corporate bond market, to be positively related to the spreads. Secondly, one- and ten-year interest rate volatility indices for the Eurozone (EIRVIXs) $)^{15}$ have also been incorporated in the analysis. A positive sign is also expected for these variables, since increased interest rate volatility is usually accompanied by an increase in yield spread volatility. Finally, to account for the concerns for the stability of the euro two variables have been used: (1) The indicator built by Klose and Weigert (2014) which reflects the market expectation of the probability that at least one euro area country will have left the currency union by the end of 2013; and (2) The time-varying probability of two or more credit events (out of ten) over a one-year horizon calculated by Lucas et al. (2013) which measures the joint default risk in the euro area. A positive relationship is also expected between the last two variables (which measure uncertainty and default risk in the euro area) and sovereign yield spreads.

As mentioned, two supplementary variables have also been introduced in the model in order to assess global market risk aversion. First, the Kansas City Financial Stress Index built by Hakkio and Keeton (2009) has been included in the analysis ${ }^{16}$ and, finally, following the empirical literature on sovereign bond spreads in emerging markets, which shows that yields on US government bonds are the main determinants of sovereign spreads, the spread between 10-year fixed interest rates on US swaps and the yield on 10year Moody's Seasoned AAA US corporate bonds is also introduced as a proxy of international risk factors (see Codogno et al., 2003 and Gómez-Puig, 2008). A positive relationship is also expected between these two variables and sovereign spreads.

\section{Empirical Results}

As mentioned before, our empirical analysis starts with a general unrestricted statistical model including all explanatory variables to capture the essential characteristics of the underlying dataset, using standard testing procedures to reduce its complexity by

\footnotetext{
${ }_{14}$ The first variable displays the spread between the yields of European corporate bonds iBoxx indices with a rating of $\mathrm{BBB}$, whilst the other two are European 5-year CDS indices in the financial and the non-financial sector respectively (the corresponding indices for the United States have been widely used in the literature: see, for instance, Gilchrist et. al., 2013).

15 They are based on the implied volatility quotes of caps (floors) - one of the most liquid interest rate derivatives- and constructed by López and Navarro (2013)

16 This is a monthly measure of stress in the US financial system based on 11 financial market variables (a positive value indicates that financial stress is above the long-run average, while a negative value signifies that financial stress is below the long-run average).
} 
eliminating statistically insignificant variables, and checking the validity of the reductions at each stage in order to ensure congruence of the finally selected model in order to find what variables explain developments best.

Tables 1 to 3 show the final results for three groups of countries: all EMU countries, EMU central countries, and EMU peripheral countries during the whole sample period: 1999:012012:12. . The reason for these three groups is that, based on a country-by-country analysis, we conclude that the EMU countries under study are not homogeneous, detecting two categories within them and allowing for differentiation in the impact of potential determinants on bond spreads in core and peripheral countries ${ }^{17}$. We report the results obtained using the Fixed Effects (FE) model since it is the relevant one in all cases ${ }^{18}$.

[Insert Tables 1 to 3 here]

The first column in these tables do not take into account the dynamic properties of sovereign spreads drivers over time; they show the results for the whole period (pre-crisis and crisis) in order to select the best model to be used in the rest of the analysis after having eliminated statistically insignificant variables. Nevertheless, some conclusions regarding the different sovereign yield spreads drivers in EMU countries are worth noting.

Concretely, Table 1 shows that the increase in the sovereign risk premium in the euro area during the European sovereign crisis cannot be attributed solely to deteriorating macroeconomic fundamentals in member countries, or to herding behaviour or sudden shifts in market confidence and expectations, but to both types of drivers. These findings are consistent with those reported by Gómez-Puig and Sosvilla-Rivero (2014a) or Dungey and Gajurel (2013) who support the idea that (since they are not mutually exclusive), a

17 The results of this sensitivity analysis to the exclusion of each country one at a time and to the elimination of the peripheral and core countries are not shown here, but are available from the authors upon request. It is interesting to note that these two groups roughly correspond to those found in Jacquemin and Sapir (1996), applying principal component and cluster analyses to a wide set of structural and macroeconomic indicators, to form a homogeneous group of countries. Moreover, these two groups are basically the same identified by European Commission (1995) when making a distinction within countries whose currencies continuously participated in the Exchange Rate Mechanism (ERM) from its inception. Two groups of countries were differentiated: those that maintained broadly stable bilateral exchange rates against the Deutschmark, and those whose currencies either entered the ERM later or suspended its participation in the ERM, fluctuating in value to a great extent relative to the Deutschmark. Finally, the same two groups are found in Fernández-Rodríguez et al. (1999) to have relevant information helping to improve the prediction of currencies in each group based on the behaviour of the rest of the currencies, information that can be used to generate simple trading rules that outperform the moving average trading rules widely used in the markets (see Fernández-Rodríguez et al.., 2003).

18 We consider three basic panel regression methods: the fixed-effects (FE) method, the random effects (RE) model and the pooled-OLS method. In order to determine the empirical relevance of each of the potential methods for our panel data, we make use of several statistic tests. In particular, we test FE versus RE using the Hausman test statistic to test for non-correlation between the unobserved effect and the regressors. To choose between pooled-OLS and RE, we use Breusch and Pagan (1980)'s Lagrange multiplier test to test for the presence of an unobserved effect. Finally, we use the F test for fixed effects to test whether all unobservable individual effects are zero, in order to discriminate between pooledOLS and RE. To save space, we do not show here these tests. They are available from the authors upon request. 
mixture of "fundamental-based" and "pure contagion" might have taken place in the Eurozone. Indeed, recent European events have encouraged a new discussion, since unlike previous crises in which the country responsible for spreading the shock was relatively clear; in the euro area sovereign debt crisis several peripheral countries entered a fiscal crisis at roughly the same time. Actually, when a group of countries share an exchange rate agreement (a common currency in the case of the euro area countries), crises tend to be clustered. In this scenario, it seems reasonable that, since the economic fundamentals of EMU countries are interconnected by their cross-border flows of goods, services, and capital, other variables beyond herding behaviour or sudden shifts in market confidence might also be at the origin of crisis propagation.

However, some differences between spreads' drivers in central and peripheral countries are worth noting. Specifically, whilst variables gauging regional macrofundamentals are more significant in central countries (Table 2) than in peripheral ones, local macrofundamentals are more relevant in explaining peripheral yields spreads than those of central countries (Table 3). Besides, whilst foreign banks' claims on the private (non-financial) sector are significant in the two groups of countries, foreign claims on the banking and public sectors are only significant in one group of countries: in central and peripheral countries respectively (see Tables 2 and 3). These results are in line with the recent literature which outlines that, in an scenario of increased international financial activity in the euro area ${ }^{19}$, not only public finances imbalances are key determinants of the probability that the sovereign debt crisis could spill over from one country to another, but that transmission of the crisis through the banking system may have also been a major issue [see Bolton and Jeanne (2011) or Allen et al. (2011), among others]. Moreover, Table 3 shows that the level of indebtedness in the banking sector is also significant driver of sovereign risk premium in peripheral countries which highlights the interconnection between private and public debt (see Acharya et al., 2014) ${ }^{20}$ and thus, between banking and sovereign crises in southern countries.

\footnotetext{
19 The introduction of the Single Banking License in 1989 through the Second Banking Directive was a decisive step towards a unified European financial market, which subsequently led to a convergence in financial legislation and regulation across member countries. 20 These authors have recently used the term "two-way feedback" to describe them. According to these authors, a systemic banking crisis can induce a contraction of the entire economy, which will weaken public finances and transfer the distress to the government. This contagion effect is amplified when state guarantees exist for the financial sector. As a feedback effect, risk is further transmitted to holders of sovereign debt. An increase in the cost of sovereign debt will lead to a devaluation of government debt, which will impair the balance sheets of banks holding these assets.
} 
Furthermore, as it has been noted before, Table 2 shows that the rise in sovereign risk in central countries, triggered by the behaviour of peripheral countries, can only partially be explained by the evolution of local macroeconomic variables in those countries (the two domestic components of sovereign risk included in its standard definition, market liquidity and credit risk, are the only ones that turn out to be significant). Conversely, it may be more related not only to regional macroeconomic fundamentals behaviour but also to local as much as regional and global market sentiment variables which reflect investors' risk aversion; since in times of uncertainty, they become more risk averse and the "flight-tosafety" motive favours bonds of countries that are generally regarded to have a low default risk (e.g., during the crisis Germany experienced one of its lowest yield levels in history). Indeed, 10-year yields spreads over Germany of Austrian, Finnish, French and Dutch government bonds achieved maximum levels of 183, 83, 189 and 84 basis points (in November 2011 in the first three countries and in April 2012 in the case of the Netherlands, see Figure 1) while the credit rating provided by the three most important agencies (Moody's, Standard \& Poor's and Fitch) at the same date was, as in Germany, the highest.

Nevertheless, since one of the objectives of this paper is to examine whether investors may have ignored cross country differences or changes in country-specific fundamentals during the stability period and may have reacted much more strongly during the crisis, we analyse the differences of coefficients' significance over time (i.e., during the pre-crisis and the crisis period). The breakpoint date has been fixed at the end of November 2009. GómezPuig and Sosvilla-Rivero (2014b), applying both the Quandt-Andrews and the Bai and Perron $(1998,2003)$ tests and letting the data select when regime shifts occurred, showed that around two thirds of the breakpoints they examine ${ }^{21}$ (i.e., 63\%) occurred after November 2009, when Papandreou's government disclosed that its finances were far worse than previously announced ${ }^{22}$. This marked the beginning of the euro area sovereign debt crisis and the onset of financial instability and risk propagation among EMU countries (see, e. g., Agarwal et al., 2013, and Yang et al., 2014).

Therefore, in addition to the independent variables explained in Section 3, in order to estimate potential changes in the marginal effects after the crisis, a dummy (DPRE) which

\footnotetext{
${ }^{21}$ In this paper, the authors explore changes in the existence and direction of causality by means of a Granger-causality approach before and after endogenously (data-based) identified crises during the period January 1999-December 2012.

22 This announcement worsened the severe crisis in the Greek economy, and the country's debt rating was lowered to $\mathrm{BBB}+$ (the lowest in the euro zone) on December $8^{\text {th }}$.
} 
takes the value 1 in the pre-crisis period (and 0, otherwise) is also introduced in the estimations and the coefficients of the interactions between this dummy and the rest of variables are calculated (see Gómez-Puig, 2006 and 2008). Thus, the marginal effects of each variable are:

$\beta=\beta_{1}+\beta_{2} \mathrm{DPRE}$

We honestly think that a formal coefficient test $\mathrm{H}_{0}: \beta_{1}=\beta_{1}+\beta_{2}$, in order to assess whether the impact of independent variables on the bond yield spreads changed significantly with the start of the sovereign debt crisis, is not necessary as long as $\beta_{2}$ is significant. So, the marginal coefficients of a variable are:

$\beta=\beta_{1}$ (in the crisis period)

$\beta=\beta_{1}+\beta_{2}$ (in the pre-crisis period)

The second column in Tables 1 to 3 shows the FE re-estimation results with the DPRE dummy. As can be seen, in all cases the marginal effects increase in the crisis period $\left(\beta_{1}\right)$ compared to the pre-crisis period $\left(\beta_{1}+\beta_{2}\right)$. Therefore, these results are in line with previous studies that point out the dynamic properties of sovereign spreads drivers over time after the start of the crisis [see, e.g., Pozzi and Wolswijk (2008), Gerlach et al. (2010), A $\beta$ mann and Boysen-Hogrefe (2012) and Bernoth and Erdogan (2012)] or which show an increase in the sensitivity of the price of risk to fundamentals during the euro area debt crisis compared with the pre-crisis period (see Beirne and Fratzscher, 2013, among them). Not only do all the variables that capture both local and regional fundamentals or market sentiment increase their significance in the two groups of countries in the crisis period compared to the pre-crisis one, but the variable that gauges global market sentiment also increases its significance after the start of the crisis in both central and peripheral EMU countries, confirming the increased importance of investors' risk aversion suggested by the literature [see Codogno et al. (2003), Sgherri and Zoli (2009) or Bernoth and Erdogan (2012), among them] in times of uncertainty.

To further investigate the possibility of differences in spread behaviour before and after the crisis period, we once again apply the general-to-specific approach, commencing from a general congruent specification that is simplified to a minimal representation consistent 
with the data evidence. The general-to-specific reduction process ensures that the final and reduced model conveys all the information embodied in the unrestricted and general one, and opens up the possibility of identifying different explanatory variables for the different subsamples we are examining (whole period, pre-crisis, and crisis period) in the diverse groups of countries (all countries, central, and peripheral countries), since it produces empirical models that are data-coherent. Results are presented in Tables 4 to 6 also, whose first column also reports the original FE estimation results (first column of Tables 1 to 3) for the whole sample period.

\section{[Insert Tables 4 to 6 here]}

The dynamic properties of sovereign yield spreads drivers over time after the start of the crisis are reaffirmed by the findings that can be drawn from Tables 4 to 6. Concretely, when analysing Table 4, which corresponds to all the countries, it is notable that the price of risk is much more sensitive to both local and regional variables (those that capture market sentiment as much as those that gauge macroeconomic fundamentals) in the crisis than in the pre-crisis period. These results suggest, on the one hand, that some important macroeconomic imbalances apart from the fiscal position (e.g. the non-financial corporations' level of indebtedness) had been largely ignored during the period of stability when markets seemed to underestimate the possibility that governments might default; and, on the other, they suggest that an important increase in the relevance of uncertainty and of variables reflecting investors' risk aversion is observed after the global financial crisis (six variables measuring regional market sentiment and one variable measuring local market sentiment were only significant in the crisis period) as pointed out by many authors [see, e.g. Favero and Missale (2012) or Georgoutsos and Migiakis (2013)].

Furthermore, Tables 5 and 6, which display the results in the three periods for central and peripheral EMU countries, show that the increase in the sensitivity of sovereign yield spreads to market sentiment and macroeconomic fundamental variables with the crisis has been much higher in peripheral (Table 6) than in central countries (Table 5).

Specifically, whilst Table 5 shows that in central EMU countries some variables which measure local market sentiment (in the case of the rating) or local macroeconomic fundamentals (the current account balance and the unemployment rate) only become significant with the crisis, Table 6 shows that, in peripheral EMU countries, five new variables are significant after the start of the crisis. One of them measures local market 
sentiment (stock volatility), two others gauge local macroeconomic imbalances (the unemployment rate and the level of indebtedness in the banking sector), and the last two are proxies of the linkages across the financial system (foreign banks' claims on public and private non-financial sector).

Again, it is noticeable that the variables measuring global market sentiment and investors' global risk aversion, which are significant in both periods, register a rise in their marginal effects after the start of the sovereign crisis, particularly in EMU peripheral countries (Table 6). This finding, which suggests that sovereign risk pricing is also related to herding behaviour of investors and other cases of extreme market sentiment, is consistent with Lux (1995) or Akerlof and Shiller (2009).

\section{Concluding remarks}

The sovereign debt crisis in Europe which began in late 2009 has revived the literature on euro area sovereign spread drivers and has highlighted the importance of uncertainty and variables reflecting investment confidence conditions and perceptions for the upcoming economic activity. This situation raises some important questions for economists. What can explain the disparities and the shift in the pricing of sovereign debt risk during the crisis period? Have the drivers of yield spreads and their relevance changed since the crisis? Are there important differences among peripheral and central countries?

The main contribution of this paper to the existing literature is methodological. We adopt an eclectic approach, using a general-to-specific modelling strategy with panel data techniques, to empirically assess the relevance of the highest number of variables proposed in the recent theoretical and empirical literature as potential drivers of EMU sovereign bond yield spreads, allowing the data to identify those variables that explain developments best for each of the three EMU groups of countries considered.

To our knowledge, this paper presents one of the most exhaustive compilations of the variables used in the literature to examine sovereign yield spreads behaviour and, in particular, to gauge the effect of changes in market sentiment and risk aversion on yield spreads, whose importance has been particularly stressed by the literature since the outbreak of the recent debt crisis. However, following the literature that re-emerged with the euro area sovereign debt crisis, the paper also examines whether there are differences between peripheral and central countries and analyses the time-varying pricing of the same 
spread drivers by market participants after the onset of the crisis. It thus represents an updated analysis of sovereign yield spread drivers in times of crisis.

All in all, looking across the columns in Tables 1 to 6 , the following conclusions can be drawn: (1) The rise in sovereign risk in central countries in the crisis period can only be partially explained by the evolution of local macroeconomic variables in those countries. Conversely, it may be related more to the behaviour of regional macroeconomic fundamentals, and also to local, regional and global market sentiment. (2) It is noticeable the increase in the significance of the banking level of indebtedness and foreign bank's claims in the public sector (mainly in peripheral countries) along with the crisis unfolding, which highlights the interconnection between private and public debt and thus, between banking and sovereign crises. (3) Besides, the variables that measure global market sentiment and investors' risk aversion, which are significant in both periods, register a rise in their marginal effects after the start of the sovereign crisis, particularly in EMU peripheral countries. These results confirm the increased importance of investors' risk aversion suggested by the literature, in times of uncertainty, when "flight-to-safety" motive favours bonds of countries that are generally regarded to have a low default risk, and consequently implies a risk premium increase in the rest of the countries. (4) In all the cases, the marginal effects of sovereign spread drivers increase in the crisis period compared to the pre-crisis period, especially in peripheral countries. Therefore, these results are in line with previous studies that stress the dynamic properties of sovereign spread determinants after the start of the crisis, showing an increase in the sensitivity of the price of risk to fundamentals during the euro area debt crisis compared with the pre-crisis period. Therefore, our results indicate that the crisis had a significant impact on the markets' reactions to macroeconomic and financial news, especially so in the peripheral countries, giving further support to previous findings by solid econometrics based on a comprehensive approach.

We consider that our results will have some practical significance for investors and policymakers and will offer some theoretical insights for academic scholars interested in the behaviour of euro area sovereign debt markets. Our methodology could be used as a tool to provide information regarding the different market prices that investors give to a wide set of factors driving EMU sovereign bond yield spreads (particularly those that measure 
market sentiment) both in periods of stability and in periods of crisis, as well as to examine whether there are important differences between central and peripheral countries.

The empirical findings documented in this study could lead to further future research about sovereign credit risk, macroeconomic fundamentals, and market sentiment. 


\section{References}

Abad, P., Chulià H. \& Goméz-Puig, M. (2010). EMU and European government bond market integration. Journal of Banking and Finance, 34, 2851-2860.

Aßmann, C. \& Boysen-Hogrefe, J. (2012). Determinants of government bond spreads in the euro area in good times as in bad. Empirica, 39, 341-356.

Acharya, V., I. Drechsler, and P.Schnabl. (2014). A Pyrrhic Victory? Bank Bailouts and Sovereign Credit Risk. The Journal of Finance, forthcoming.

Ades, A. \& Chua, H.B. (1993). Regional instability and economic growth: Thy neigbor's curse. Discussion Paper 704, Economic Growth Center, Yale University.

Afonso, A., Arghyrou, M.G. \& Kontonikas, A. (2012). The determinants of sovereign bond yield spreads in the EMU. Working Paper 36, Department of Economics, Technical University of Lisbon.

Agarwal, M., Walsh, S., Wang, J., Whalley, J. \& Yan, C. (2013). Expected worsening or improving financial instability and the 2008 financial crisis. The North American Journal of Economics and Finance, 26, 92-105.

Aizenman, J., Binici, M. \& Hutchison, M. M. (2013). Credit ratings and the pricing of sovereign debt during the euro crisis. Working Paper 19125, National Bureau of Economic Research.

Akerlof, G. A. \& Shiller, R. J. (2009). Animal spirits. Princeton: Princeton University Press.

Allen, F.; Beck; T., Carletti; E., Lane; P. L., Schoenmaker, D. \& Wagner, W. (2011). Crossborder banking in Europe: Implications for financial stability and macroeconomic policies. London: Centre for Economic Policy Research.

Andrews, D. W. K. (1993). Tests for parameter instability and structural change with unknown change point. Econometrica, 61, 821-856.

Andrews, D. \& Ploberger, W. (1994). Optimal tests when a nuisance parameter is present only under the alternative. Econometrica, 62, 1383-1414.

Baele, L., Ferrando, A., Hördahl, P., Krylova, E. \& Monnet, C. (2004). Measuring European financial integration. Oxford Review of Economic Policy, 20, 509-530.

Bai, J., Perron, P. (1998). Estimating and testing linear models with multiple structural changes. Econometrica, 66, 47-78.

Bai, J., Perron, P. (2003). Computation and analysis of multiple structural change models. Journal of Applied Econometrics, 6, 72-78.

Baker, S.R., Bloom, N. \& Davis, S. J. (2013). Measuring economic policy uncertainty. Working Paper 13-02, Booth School of Business, The University of Chicago.

Baltagi, B. D. (2008). Econometric analysis of panel data, fourth ed. Chichester: John Wiley \& Sons.

Barrios, S.; Iversen; P., Lewandowska M. \& Setze, R. (2009). Determinants of intra-euro area government bond spreads during the financial crisis. Economic Paper 388, European Commission.

Battistini, N., Pagano, M. \& Simonelli, S. (2013). Systemic risk, sovereign risk and bank exposures in the euro crisis. Working Paper 345, Centre for Studies in Economics and Finance. 
Bayoumi, T., Goldstein, M. \& Woglom, G. (1995). Do credit markets discipline sovereign borrowers? Evidence from the US States. Journal of Money, Credit and Banking, 27, 1046-1059.

Beirne, J. \& Fratzscher, M. (2013). The pricing of sovereign risk and contagion during the European sovereign debt crisis. Journal of International Money and Finance, 34, 60-82.

Bernoth, K. \& Erdogan, B. (2012). Sovereign bond yield spreads: A time-varying coefficient approach. Journal of International Money and Finance, 31, 975-995.

Blanco, R. (2001). The Euro-area government securities markets. Recent developments and implications for market functioning. Working Paper 0120, Banco de España.

Bolton, P. \& Jeanne, O. (2011). Sovereign default risk and bank fragility in financially integrated economies. Discussion Paper 8368, Centre for Economic Policy Research.

Breusch, T. S. \& Pagan, A R. (1980). The Lagrange multiplier test and its applications to model specification in econometrics. Review of Economic Studies, 47, 239-253.

Brunnermeier, M.K., L.Garicano, P.R. Lane, M.Pagano, R.Reis, T.Santos, S. Van Nieuwerburgh, and D.Vayanos. (2011). European Safe Bonds: ESBies.www.euronomics.com.

Caceres, C., Vicenzo, G. \& Segoviano Basurto, M. A. (2010). Sovereign spreads: Global risk aversion, contagion or fundamentals. Working paper 10/120, International Monetary Fund.

Codogno, L., Favero, C. \& Missale, A. (2003). Yield spreads on EMU government bonds. Economic Policy, 18, 503-532.

Dornbusch, R., Park, Y. C. \& Claessens, S. (2000). Contagion: Understanding how it spreads. The World Bank Research Observer, 15, 177-198.

Dötz, N. \& Fischer, C. (2010). What can EMU countries' sovereign bond spreads tell us about market perceptions of default probabilities during the recent financial crisis? Economic Studies, 2010-11, Deutsche Bundesbank.

Dungey, M., Gajurel, D. (2013). Equity market contagion during the global financial crisis: Evidence from the World's eight largest economies. Working Paper 15, UTAS School of Economics and Finance.

European Commission (1995). The impact of exchange rate movements on trade within the single market. European Economy, Reports and Studies, 4.

Favero, C. \& Missale, A. (2012). Sovereign spreads in the Euro area: which prospects for a Eurobond? Economic Policy, 27, 231-270.

Fernández-Rodríguez, F., Sosvilla-Rivero, S. \& Andrada-Félix, J. (1999). Exchange-rate forecasts with simultaneous nearest-neighbour methods: evidence from the EMS. International Journal of Forecasting, 15, 383-392.

Fernández-Rodríguez, F., Sosvilla-Rivero, S. \& Andrada-Félix, J. (2003) Technical analysis in foreign exchangemarkets: evidence from the EMS, Applied Financial Economics, 13, 113122.

Gerlach, S., Schulz, A. \& Wolff, G. B. (2010) Banking and sovereign risk in the euro area. Economic Studies, 2010-09, Deutsche Bundesbank.

Georgoutsos, D. A. \& Migiakis, P. M. (2013). Heterogeneity of the determinants of euroarea sovereign bond spreads: What does it tell us about financial stability? Journal of Banking and Finance, 37, 4650-4664. 
Geyer, A., Kossmeier, S. \& Pichler, S., 2004. Measuring systematic risk in EMU government yield spreads. Review of Finance, 8, 171-197.

Gilchrist, S. \& Zakrajsek, E. (2013). The impact of the Federal Reserve's large-scale asset purchase programs on corporate credit risk. Working Paper 19337, National Bureau of Economic Research.

Gómez-Puig, M. (2006). Size matters for liquidity: Evidence from EMU sovereign yield spreads. Economics Letters, 90, 156-162.

Gómez-Puig, M. (2008). Monetary integration and the cost of borrowing. Journal of International Money and Finance, 27, 455-479.

Goméz-Puig, M. (2009). Systemic and idiosyncratic risk in EU-15 sovereign yield spreads after seven years of monetary union. European Financial Management, 15, 971-1000.

Gómez-Puig, M. \& Sosvilla-Rivero, S. (2013). Granger-causality in peripheral EMU public debt markets: A dynamic approach. Journal of Banking and Finance, 37, 4627-4649.

Gómez-Puig, M. \& Sosvilla-Rivero, S. (2014a). EMU sovereign debt markets crisis: Fundamental-based or pure contagion? Working Paper 2014/02, Institut de Recerca en Economia Aplicada Regional i Pública, Universitat de Barcelona.

Gómez-Puig, M. \& Sosvilla-Rivero, S. (2014b). Causality and contagion in EMU sovereign debt markets. International Review of Economics and Finance, 33, 12-27.

Hakkio, C. S. \& Keeton, W. R. (2009). Financial stress: What is it, how can it be measured, and why does it matter? Federal Reserve Bank of Kansas City Economic Review, second quarter, $5-50$.

Hsiao, C. (2007). Panel data analysis: Advantages and challenges. Test, 16, 1-22.

International Monetary Fund (2010). Global Financial Stability Report, April, International Monetary Fund, Washington, D. C.

Jacquemin. A. \& Sapir, A. (1996) Is a European hard core credible? A statistical analysis, Kyklos, 49, 105-117.

Klose, J. \& Weigert, B. (2014). Sovereign yield spreads during the Euro-crisis: Fundamental factors versus redenomination risk. International Finance, 17, 25-50.

Kocenda, E., Kutan, A. M. \& Yigit, T. M. (2008). Fiscal convergence in the European Union. North Americal Journal of Economics and Finance, 19, 319-330.

Korajczyk, R. \& Sadka, R. (2008). Pricing the commonality across alternative measures of liquidity. Journal of Financial Economics, 87, 45-72.

López, R. \& Navarro, E. (2013). Interest rate and stock return volatility indices for the Eurozone. Investors' gauges of fear during the recent financial crisis. Applied Financial Economics, 23, 1419-1432.

Lucas, A., Schwaab, B. \& Zhang, X. (2013). Conditional euro area sovereign default risk. Working Paper 269, Sveriges Riksbank.

Lux, T. (1995). Herd behaviour, bubbles and crashes. The Economic Journal, 105, 881-896.

Masson, P. (1999). Contagion: Macroeconomic models with multiple equilibria. Journal of International Money and Finance, 18, 587-602.

Mody, A. (2009). From bear sterns to Anglo Irish: How Eurozone sovereign spreads related to financial sector vulnerability. Working Paper 09/108, International Monetary Fund. 
Mondria, J. \& Quintana-Domeque, C. (2013). Financial contagion and attention allocation. The Economic Journal, 123, 429-454.

Pagano, M. \& von Thadden, L. (2004). The European bond markets under EMU. Oxford Review of Economic Policy, 20, 531-554.

Palladini, G. \& Portes, R. (2011). Sovereign CDS and bond pricing in the Euro Area. Working Paper 17586, National Bureau of Economic Research.

Polito, V. \& Wickens, M. (2011). Assessing the fiscal stance in the European Union and the United States, 1970-2011. Economic Policy, 26, 599-647.

Polito, V. \& Wickens, M. (2012). A model-based indicator of the fiscal stance. European Economic Review, 56, 526-551.

Pozzi, L. \& Wolswijk, G. (2008). Have Euro Area government bond risk premia converged to their common state? Discussion Paper 08-042/2, Tinbergen Institute.

Quandt, R. E. (1960). Tests of the hypothesis that a linear regression system obeys two separate regimes. Journal of the American Statistical Association, 55, 324-330.

Reichlin, L. (2013). The ECB and the banks: the tale of two crises. CEPR Discussion Paper No. 964

Rua, A. (2002). Composite indicators for the Euro area economic activity. Banco de Portugal Economic Bulletin, September, pp. 87-100.

Schuknecht, L., Von Hagen, J. \& Wolswijk, G. (2009). Government risk premiums in the bond market: EMU and Canada. European Journal of Political Economy, 25, 371-384.

Sgherri, S. \& Zoli, E. (2009). Euro area sovereign risk during the crisis. Working Paper 09/222, International Monetary Fund.

Von Hagen, J., Schuknecht, L. \& Wolswijk, G. (2011). Government bond risk premiums in the EU revisited: The impact of the financial crisis. European Journal of Political Economy, 27, $36-43$.

White, H. (1980). A heteroskedasticity-consistent covariance matrix estimator and a direct test for heteroskedasticity. Econometrica, 48, 817-838.

Yang, H.-F., Liu, C.-L. \& Chou, R. Y. (2014). Interest rate risk propagation: Evidence from the credit crunch. The North American Journal of Economics and Finance, 28, 242-264 
Figure 1. Daily 10-year sovereign yield spreads over Germany: 1999-2012

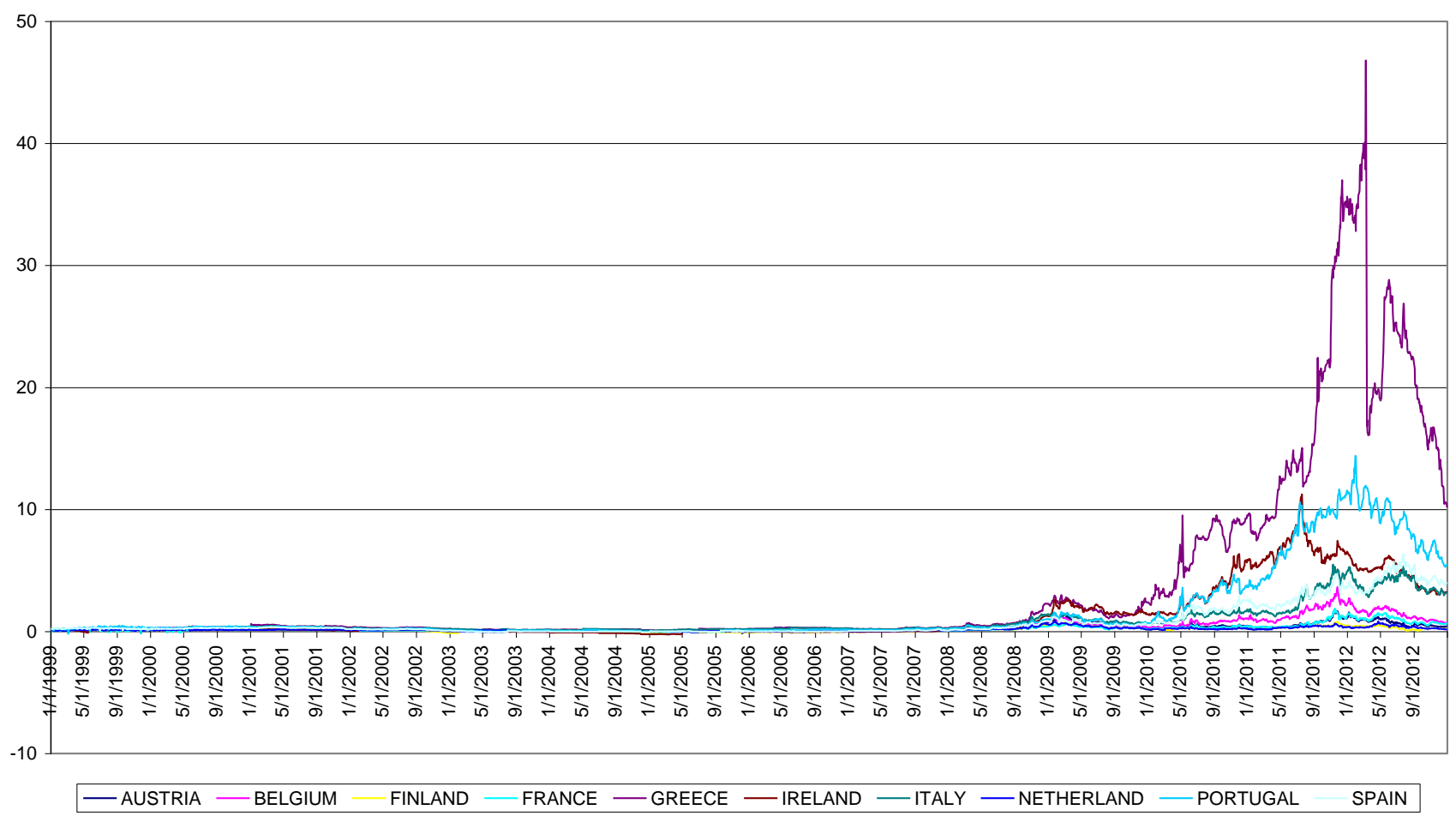


Table 1. Panel regression: All countries, pre- and crisis analysis with dummies

\begin{tabular}{|c|c|c|}
\hline & Without dummies & With dummies \\
\hline Constant & $\begin{array}{l}2.9474 * \\
(3.3173)\end{array}$ & $\begin{array}{l}2.9316^{*} \\
(2.9636)\end{array}$ \\
\hline DPRE & & $\begin{array}{c}-0.1083^{*} \\
(-3.3306)\end{array}$ \\
\hline \multicolumn{3}{|l|}{ Local market sentiment } \\
\hline RAT & $\begin{array}{c}0.3371^{*} \\
(27.9692)\end{array}$ & $\begin{array}{c}0.4903^{*} \\
(25.2733)\end{array}$ \\
\hline DPRE*RAT & & $\begin{array}{l}-0.1968^{*} \\
(-4.5171) \\
\end{array}$ \\
\hline \multicolumn{3}{|c|}{ Regional market sentiment } \\
\hline EuroIRVIX-1Y & $\begin{array}{l}0.0147 * \\
(3.4001)\end{array}$ & $\begin{array}{l}0.0157 \\
(0.5928) \\
\end{array}$ \\
\hline DPRE*EuroIRVIX-1Y & & $\begin{array}{c}-0.0012 \\
(-1.2913) \\
\end{array}$ \\
\hline EuroIRVIX-10Y & $\begin{array}{l}0.0776^{*} \\
(3.8115) \\
\end{array}$ & $\begin{array}{l}0.0836^{*} \\
(4.1129) \\
\end{array}$ \\
\hline DPRE*EuroIRVIX-10Y & & $\begin{array}{c}-0.0135^{*} \\
(-2.1201) \\
\end{array}$ \\
\hline \multicolumn{3}{|c|}{ Local macrofundamentals } \\
\hline CAC & $\begin{array}{l}-0.0642^{*} \\
(-2.6463) \\
\end{array}$ & $\begin{array}{c}-0.0733^{*} \\
(-4.1197) \\
\end{array}$ \\
\hline DPRE*CAC & & $\begin{array}{l}0.0106^{*} \\
(5.4637) \\
\end{array}$ \\
\hline DEF & $\begin{array}{l}0.0306^{*} \\
(3.1158)\end{array}$ & $\begin{array}{c}0.0451 \\
(1.3906)\end{array}$ \\
\hline DPRE*DEF & & $\begin{array}{c}-0.0183 \\
(-0.8721) \\
\end{array}$ \\
\hline LIQ & $\begin{array}{l}-0 . .0011^{*} \\
(-3.3517) \\
\end{array}$ & $\begin{array}{l}-0.0017^{*} \\
(-3.1538) \\
\end{array}$ \\
\hline DPRE*LIQ & & $\begin{array}{c}0.0004^{* *} \\
(2.3328) \\
\end{array}$ \\
\hline BANDEBT & $\begin{array}{l}00067^{*} \\
(5.1629) \\
\end{array}$ & $\begin{array}{l}00073^{*} \\
(5.3906) \\
\end{array}$ \\
\hline DPRE*BANDEBT & & $\begin{array}{l}-0.0024^{*} \\
(-2.7501) \\
\end{array}$ \\
\hline \multicolumn{3}{|c|}{ Regional macrofundamentals } \\
\hline EuroGOVDEBT & $\begin{array}{l}0.0799 * \\
(5.1716) \\
\end{array}$ & $\begin{array}{l}0.0836^{*} \\
(3.1201) \\
\end{array}$ \\
\hline DPRE*EuroGOVDEBT & & $\begin{array}{c}-0.0124^{*} \\
(-2.6278) \\
\end{array}$ \\
\hline \multicolumn{3}{|l|}{ Financial linkages } \\
\hline EXTDEBTPUB & $\begin{array}{c}0.1194 * \\
(14.1451) \\
\end{array}$ & $\begin{array}{l}0.1279 * \\
(5.9066) \\
\end{array}$ \\
\hline DPRE*EXTDEBTPUB & & $\begin{array}{c}-0.0211 \\
(-0.8983)\end{array}$ \\
\hline $\mathrm{R}^{2}$ & 0.8246 & 0.8446 \\
\hline
\end{tabular}

Notes: FE regression results. In the ordinary brackets below the parameter estimates are the corresponding $z$-statistics, computed using White (1980)'s heteroskedasticity-robust standard errors. In the square brackets below the specification tests are the associated $p$-values. $* * *$ and $* * *$ indicate significance at $1 \%, 5 \%$, and $10 \%$ respectively. 
Table 2. Panel regression: Central countries, pre- and crisis analysis with dummies

\begin{tabular}{|c|c|c|}
\hline & Without dummies & With dummies \\
\hline Constant & $\begin{array}{c}-2.4938^{*} \\
(-13.0438) \\
\end{array}$ & $\begin{array}{c}-2.5632^{*} \\
(-12.0696) \\
\end{array}$ \\
\hline DPRE & & $\begin{array}{l}0.0139 * \\
(2.8252)\end{array}$ \\
\hline \multicolumn{3}{|l|}{ Local market sentiment } \\
\hline RAT & $\begin{array}{c}0.0270^{* *} \\
(2.1263)\end{array}$ & $\begin{array}{l}0.0447^{*} \\
(4.4323)\end{array}$ \\
\hline DPRE* RAT & & $\begin{array}{c}-0.0158^{* *} \\
(-2.5171)\end{array}$ \\
\hline \multicolumn{3}{|c|}{ Regional market sentiment } \\
\hline EuroEPU & $\begin{array}{l}0.0036^{*} \\
(6.7169)\end{array}$ & $\begin{array}{l}0.0048^{*} \\
(5.0857)\end{array}$ \\
\hline DPRE*EuroEPU & & $\begin{array}{l}-0.0011 * \\
(-3.3398)\end{array}$ \\
\hline EuroCSPREAD & $\begin{array}{c}0.0555^{*} \\
(13.2188)\end{array}$ & $\begin{array}{l}0.0618^{*} \\
(6.5218)\end{array}$ \\
\hline DPRE* EuroCSPREAD & & $\begin{array}{c}-0.0115^{* * *} \\
(-.8293) \\
\end{array}$ \\
\hline \multicolumn{3}{|l|}{ Global market sentiment } \\
\hline GlobalRISK & $\begin{array}{l}0.1758^{*} \\
(5.4374)\end{array}$ & $\begin{array}{c}0.1928 * * \\
(2.8385) \\
\end{array}$ \\
\hline DPRE*GlobalRISK & & $\begin{array}{l}-0.0650^{*} \\
(-2.6443)\end{array}$ \\
\hline \multicolumn{3}{|c|}{ Local macrofundamentals } \\
\hline GOVDEBT & $\begin{array}{l}0.0209^{*} \\
(5.5755)\end{array}$ & $\begin{array}{l}0.0234^{*} \\
(5.4094)\end{array}$ \\
\hline DPRE*GOVDEBT & & $\begin{array}{l}-0.0011 * \\
(-3.9705)\end{array}$ \\
\hline LIQ & $\begin{array}{l}-0.0007 * \\
(-6.9412)\end{array}$ & $\begin{array}{c}-0.0008^{*} \\
(-6.2514)\end{array}$ \\
\hline DPRE*LIQ & & $\begin{array}{c}0.0003^{* *} \\
(1.9612)\end{array}$ \\
\hline \multicolumn{3}{|c|}{ Regional macrofundamentals } \\
\hline EuroGOVDEBT & $\begin{array}{l}0.0176^{*} \\
(6.6267)\end{array}$ & $\begin{array}{l}0.0284^{*} \\
(3.1095)\end{array}$ \\
\hline DPRE* EuroGOVDEBT & & $\begin{array}{l}-0.0091 * \\
(-5.2763)\end{array}$ \\
\hline EuroLIQ & $\begin{array}{c}-0.0002^{*} \\
(-10.7158)\end{array}$ & $\begin{array}{l}-0.0005^{*} \\
(-7.4087) \\
\end{array}$ \\
\hline DPRE* EuroLIQ & & $\begin{array}{l}0.0002^{*} \\
(6.0555)\end{array}$ \\
\hline \multicolumn{3}{|l|}{ Financial linkages } \\
\hline EXTDEBTPRI & $\begin{array}{c}0.0051^{*} \\
(10.5303) \\
\end{array}$ & $\begin{array}{l}0.0064 * \\
(4.1345) \\
\end{array}$ \\
\hline DPRE*EXTDEBTPRI & & $\begin{array}{c}-0.0008^{*} \\
(-3.8016)\end{array}$ \\
\hline EXTDEBTBAN & $\begin{array}{c}0.0127^{*} \\
(10.5328) \\
\end{array}$ & $\begin{array}{l}0.0143^{*} \\
(9.3655) \\
\end{array}$ \\
\hline DPRE*EXTDEBTBAN & & $\begin{array}{c}-0.0033^{*} \\
(-7.1758)\end{array}$ \\
\hline $\mathrm{R}^{2}$ & 0.8071 & 0.8609 \\
\hline
\end{tabular}

Notes: FE regression results. In the ordinary brackets below the parameter estimates are the corresponding $z$-statistics, computed using White (1980)'s heteroskedasticity-robust standard errors. In the square brackets below the specification tests are the associated $p$-values. $*, * *$ and $* * *$ indicate significance at $1 \%, 5 \%$ and $10 \%$ respectively. 
Table 3. Panel regression: Peripheral countries, pre- and crisis analysis with dummies

\begin{tabular}{|c|c|c|}
\hline & Without dummies & With dummies \\
\hline Constant & $\begin{array}{l}4.1544^{*} \\
(8.5911)\end{array}$ & $\begin{array}{l}4.2998^{*} \\
(8.1812)\end{array}$ \\
\hline DPRE & & $\begin{array}{c}-0.1023^{*} \\
(-5.5415)\end{array}$ \\
\hline \multicolumn{3}{|l|}{ Local market sentiment } \\
\hline STOCKV & $\begin{array}{c}26.4743^{* *} \\
(2.3136)\end{array}$ & $\begin{array}{c}35.9449^{*} \\
(5.6338)\end{array}$ \\
\hline DPRE*STOCKV & & $\begin{array}{c}-12.5844^{*} \\
(-5.8913)\end{array}$ \\
\hline IFS & $\begin{array}{l}2.8091 * \\
(5.6425)\end{array}$ & $\begin{array}{l}2.9795^{*} \\
(5.2706)\end{array}$ \\
\hline DPRE*IFS & & $\begin{array}{c}-0.2585^{*} \\
(-5.1423) \\
\end{array}$ \\
\hline \multicolumn{3}{|c|}{ Regional market sentiment } \\
\hline EuroCSPREAD & $\begin{array}{l}0.2434 * \\
(6.7736)\end{array}$ & $\begin{array}{l}0.2786^{*} \\
(4.9798)\end{array}$ \\
\hline DPRE* EuroCSPREAD & & $\begin{array}{l}-0.0342^{*} \\
(-3.3927) \\
\end{array}$ \\
\hline \multicolumn{3}{|c|}{ Global market sentiment } \\
\hline GlobalIFS & $\begin{array}{l}0.3252^{*} \\
(3.5509) \\
\end{array}$ & $\begin{array}{c}0.3705^{* *} \\
(2.4017) \\
\end{array}$ \\
\hline DPRE*GlobalIFS & & $\begin{array}{c}-0.0741 * \\
(-2.4567) \\
\end{array}$ \\
\hline \multicolumn{3}{|c|}{ Local macrofundamentals } \\
\hline $\mathrm{U}$ & $\begin{array}{l}0.3325^{*} \\
(8.8743)\end{array}$ & $\begin{array}{l}0.3534^{*} \\
(4.4835)\end{array}$ \\
\hline DPRE*U & & $\begin{array}{c}-0.0399 * * * \\
(-1.7316) \\
\end{array}$ \\
\hline GOVDEBT & $\begin{array}{c}0.2261^{*} \\
(22.2359)\end{array}$ & $\begin{array}{c}0.2815^{*} \\
(17.4315)\end{array}$ \\
\hline DPRE*GOVDEBT & & $\begin{array}{c}-0.0613^{*} \\
(-10.1341)\end{array}$ \\
\hline BANDEBT & $\begin{array}{l}0.0216^{*} \\
(6.1008) \\
\end{array}$ & $\begin{array}{c}0.0298^{* * *} \\
(1.7781)\end{array}$ \\
\hline DPRE*BANDEBT & & $\begin{array}{c}-0.0087 \\
(-0.5462)\end{array}$ \\
\hline NFCDEBT & $\begin{array}{l}0.0469 * \\
(3.0716) \\
\end{array}$ & $\begin{array}{l}0.0549 * \\
(7.6372) \\
\end{array}$ \\
\hline DPRE*NFCDEBT & & $\begin{array}{l}-0.0087 * \\
(-8.4457)\end{array}$ \\
\hline \multicolumn{3}{|c|}{ Regional macrofundamentals } \\
\hline EuroGOVDEBT & $\begin{array}{l}.1883^{*} \\
(4.8521\end{array}$ & $\begin{array}{l}0.2033^{*} \\
(4.7515) \\
\end{array}$ \\
\hline DPRE*EuroGOVDEBT & & $\begin{array}{l}-0.0216^{*} \\
(-4.3156)\end{array}$ \\
\hline \multicolumn{3}{|l|}{ Financial linkages } \\
\hline EXTDEBTPUB & $\begin{array}{c}0.1966^{*} \\
(15.8665) \\
\end{array}$ & $\begin{array}{c}0.2343^{* * *} \\
(1.7765) \\
\end{array}$ \\
\hline DPRE*EXTDEBTPUB & & $\begin{array}{l}-0.0601 * \\
(-1.9863)\end{array}$ \\
\hline EXTDEBTPRI & $\begin{array}{l}0.0299 * \\
(4.5906)\end{array}$ & $\begin{array}{l}0.0354^{*} \\
(2.9834)\end{array}$ \\
\hline DPRE*EXTDEBTPRI & & $\begin{array}{c}-0.0096 \\
(-0.5314)\end{array}$ \\
\hline $\mathrm{R}^{2}$ & 0.8798 & 0.9145 \\
\hline
\end{tabular}

Notes: FE regression results. In the ordinary brackets below the parameter estimates are the corresponding z-statistics, computed using White (1980)'s heteroskedasticity-robust standard errors. In the square brackets below the specification tests are the associated $p$-values. ${ }^{*}, * *$ and $* *$ indicate significance at $1 \%, 5 \%$ and $10 \%$ respectively. 
Table 4. Panel regression: All countries, pre- and crisis re-estimation analysis

\begin{tabular}{|c|c|c|c|}
\hline & All sample & Pre-crisis period & Crisis period \\
\hline Constant & $\begin{array}{l}2.9474 * \\
(3.3173)\end{array}$ & $\begin{array}{c}0.3329 \\
(0.9823) \\
\end{array}$ & $\begin{array}{l}3.6353^{*} \\
(4.3749)\end{array}$ \\
\hline \multicolumn{4}{|c|}{ Local market sentiment } \\
\hline RAT & $\begin{array}{c}0.3371 * \\
(27.9692)\end{array}$ & & \\
\hline STOCKV & & $\begin{array}{l}7.3069^{*} \\
(3.5833)\end{array}$ & $\begin{array}{l}10.1604^{*} \\
(2.7909)\end{array}$ \\
\hline IFS & & & $\begin{array}{l}2.1922^{*} \\
(8.1228)\end{array}$ \\
\hline \multicolumn{4}{|c|}{ Regional market sentiment } \\
\hline EuroCCI & & & $\begin{array}{c}0.4855^{* *} \\
(2.4135)\end{array}$ \\
\hline EuroIRVIX-1Y & $\begin{array}{l}0.0147 * \\
(3.4001)\end{array}$ & & $\begin{array}{l}0.4160^{*} \\
(4.0323)\end{array}$ \\
\hline EuroIRVIX-10Y & $\begin{array}{l}0.0776^{*} \\
(3.8115)\end{array}$ & & $\begin{array}{l}1.1245^{*} \\
(4.6276)\end{array}$ \\
\hline EuroCSPREAD & & & $\begin{array}{l}2.9225^{*} \\
(4.4721)\end{array}$ \\
\hline EuroITRAXX ${ }_{\mathrm{FIN}}$ & & & $\begin{array}{l}0.0728^{*} \\
(4.6106)\end{array}$ \\
\hline EuroITRAXX $_{\mathrm{NF}}$ & & & $\begin{array}{l}0.2970^{*} \\
(4.5436)\end{array}$ \\
\hline EuroDEFAULT & & $\begin{array}{l}15.9903 * \\
(9.0031)\end{array}$ & \\
\hline EuroSTOCKV & & $\begin{array}{l}0.0153^{*} \\
(5.2026) \\
\end{array}$ & $\begin{array}{l}0.7059^{*} \\
(3.7908) \\
\end{array}$ \\
\hline \multicolumn{4}{|c|}{ Global market sentiment } \\
\hline GlobalIFS & & $\begin{array}{l}0.0153^{*} \\
(6.1749) \\
\end{array}$ & $\begin{array}{l}5.7669^{*} \\
(2.8654) \\
\end{array}$ \\
\hline \multicolumn{4}{|c|}{ Local macrofundamentals } \\
\hline CAC & $\begin{array}{l}-0.0642 * \\
(-2.6463)\end{array}$ & & \\
\hline DEF & $\begin{array}{l}0.0306^{*} \\
(3.1158)\end{array}$ & $\begin{array}{c}0.0572^{*} \\
(13.2614)\end{array}$ & $\begin{array}{l}0.0661 * * \\
(2.2427)\end{array}$ \\
\hline GOVDEBT & & & $\begin{array}{l}0.2536^{*} \\
(5.4535)\end{array}$ \\
\hline LIQ & $\begin{array}{l}-0 . .0011 * \\
(-3.3517) \\
\end{array}$ & $\begin{array}{l}-0.0085^{*} \\
(-3.0849) \\
\end{array}$ & \\
\hline BANDEBT & $\begin{array}{l}00067^{*} \\
(5.1629)\end{array}$ & & \\
\hline HOUDEBT & & $\begin{array}{l}0.0265^{*} \\
(5.1197)\end{array}$ & $\begin{array}{l}0.0443^{*} \\
(4.4382)\end{array}$ \\
\hline NFCDEBT & & & $\begin{array}{c}0.1328^{* *} \\
(2.4782) \\
\end{array}$ \\
\hline INF & & $\begin{array}{l}0.1092^{*} \\
(5.5294)\end{array}$ & $\begin{array}{c}0.4193^{* * *} \\
(1.9905)\end{array}$ \\
\hline $\bar{U}$ & & $\begin{array}{l}0.0481^{*} \\
(3.1414) \\
\end{array}$ & $\begin{array}{c}2.2909^{*} \\
(11.6623) \\
\end{array}$ \\
\hline \multicolumn{4}{|c|}{ Regional macrofundamentals } \\
\hline EuroDEF & & & $\begin{array}{l}2.7244^{*} \\
(4.0834) \\
\end{array}$ \\
\hline EuroGOVDEBT & $\begin{array}{c}0.0799 * \\
(5.1716)\end{array}$ & & $\begin{array}{l}0.2535^{*} \\
(4.3467) \\
\end{array}$ \\
\hline \multicolumn{4}{|c|}{ Financial linkages } \\
\hline EXTDEBTPUB & $\begin{array}{c}0.1194 * \\
(14.1451)\end{array}$ & $\begin{array}{l}0.0655^{*} \\
(7.6197)\end{array}$ & $\begin{array}{l}0.1072^{*} \\
(3.9608)\end{array}$ \\
\hline $\mathrm{R}^{2}$ & 0.8246 & 0.8466 & 0.8591 \\
\hline
\end{tabular}

Notes: FE regression results. In the ordinary brackets below the parameter estimates are the corresponding $₹$-statistics, computed using White (1980)'s heteroskedasticity-robust standard errors. In the square brackets below the specification tests are the associated $p$-values. $*, * *$ and $* * *$ indicate significance at $1 \%, 5 \%$, and $10 \%$ respectively. 
Table 5. Panel regression: Central countries, pre- and crisis re-estimation analysis

\begin{tabular}{|c|c|c|c|}
\hline & All sample & Pre-crisis period & Crisis period \\
\hline Constant & $\begin{array}{c}-2.4938^{*} \\
(-13.0438)\end{array}$ & $\begin{array}{c}-7.1999 * * \\
(2.5963)\end{array}$ & $\begin{array}{l}3.5944^{*} \\
(8.2816)\end{array}$ \\
\hline \multicolumn{4}{|c|}{ Local market sentiment } \\
\hline RAT & $\begin{array}{c}0.0270^{* *} \\
(2.1263)\end{array}$ & & $\begin{array}{c}0.1054^{*} \\
(3.0111)\end{array}$ \\
\hline IFS & & $\begin{array}{c}0.4999 * * \\
(2.5071)\end{array}$ & $\begin{array}{c}3.1317^{*} \\
(11.4726)\end{array}$ \\
\hline \multicolumn{4}{|c|}{ Regional market sentiment } \\
\hline EuroEPU & $\begin{array}{l}0.0036^{*} \\
(6.7169)\end{array}$ & & $\begin{array}{l}0.0054^{*} \\
(5.3616)\end{array}$ \\
\hline EuroCSPREAD & $\begin{array}{c}0.0555^{*} \\
(13.2188)\end{array}$ & & $\begin{array}{l}0.1547^{*} \\
(7.4048)\end{array}$ \\
\hline EuroIRVIX-1Y & & $\begin{array}{l}0.0171 * \\
(2.6841) \\
\end{array}$ & \\
\hline EuroIRVIX-10Y & & $\begin{array}{l}0.0342^{*} \\
(3.1638)\end{array}$ & \\
\hline EuroITRAXX $_{\mathrm{NF}}$ & & & $\begin{array}{l}0.0039 * \\
(4.2256)\end{array}$ \\
\hline EuroDEFAULT & & $\begin{array}{c}13.8892^{*} \\
(5.5754)\end{array}$ & \\
\hline EuroSTOCKV & & $\begin{array}{l}0.0094^{*} \\
(3.6949)\end{array}$ & \\
\hline \multicolumn{4}{|c|}{ Global market sentiment } \\
\hline GlobalRISK & $\begin{array}{l}0.1758^{*} \\
(5.4374)\end{array}$ & $\begin{array}{l}0.1298^{*} \\
(5.1105)\end{array}$ & $\begin{array}{l}0.1462^{*} \\
(4.3547)\end{array}$ \\
\hline \multicolumn{4}{|c|}{ Local macrofundamentals } \\
\hline CAC & & & $\begin{array}{l}-0.0582^{*} \\
(-4.1234)\end{array}$ \\
\hline GOVDEBT & $\begin{array}{l}0.0209^{*} \\
(5.5755) \\
\end{array}$ & $\begin{array}{l}0.0206^{*} \\
(4.4667) \\
\end{array}$ & $\begin{array}{c}0.0892^{*} \\
(11.2212) \\
\end{array}$ \\
\hline LIQ & $\begin{array}{l}-0.0007^{*} \\
(-6.9412)\end{array}$ & $\begin{array}{l}-0.0004^{*} \\
(-2.9461)\end{array}$ & $\begin{array}{l}-0.0039 * \\
(-8.1567)\end{array}$ \\
\hline $\mathrm{U}$ & & & $\begin{array}{l}0.1860^{*} \\
(3.6269)\end{array}$ \\
\hline \multicolumn{4}{|c|}{ Regional macrofundamentals } \\
\hline EuroGOVDEBT & $\begin{array}{l}0.0176^{*} \\
(6.6267)\end{array}$ & $\begin{array}{l}0.0148^{*} \\
(3.4253)\end{array}$ & $\begin{array}{l}0.1105^{*} \\
(8.2755)\end{array}$ \\
\hline EuroLIQ & $\begin{array}{c}-0.0002^{*} \\
(-10.7158) \\
\end{array}$ & $\begin{array}{l}-0.0001^{*} \\
(-9.8334)\end{array}$ & $\begin{array}{l}-0.0004^{*} \\
(-8.2735) \\
\end{array}$ \\
\hline \multicolumn{4}{|c|}{ Financial linkages } \\
\hline EXTDEBTPRI & $\begin{array}{c}0.0051^{*} \\
(10.5303) \\
\end{array}$ & $\begin{array}{l}0.0231^{*} \\
(3.7814)\end{array}$ & $\begin{array}{l}0.0039 * \\
(3.3728) \\
\end{array}$ \\
\hline EXTDEBTBAN & $\begin{array}{c}0.0127^{*} \\
(10.5328)\end{array}$ & $\begin{array}{l}0.0099 * \\
(6.2242)\end{array}$ & $\begin{array}{l}0.0104^{*} \\
(4.3216)\end{array}$ \\
\hline $\mathrm{R}^{2}$ & 0.8071 & 0.9456 & 0.9515 \\
\hline
\end{tabular}

Notes: FE regression results. In the ordinary brackets below the parameter estimates are the corresponding z-statistics, computed using White (1980)'s heteroskedasticity-robust standard errors. In the square brackets below the specification tests are the associated $p$-values. $*, * *$ and $* * *$ indicate significance at $1 \%, 5 \%$, and $10 \%$ respectively. 
Table 6. Panel regression: Peripheral countries, pre- and crisis re-estimation analysis

\begin{tabular}{|c|c|c|c|}
\hline & All sample & Pre-crisis period & Crisis period \\
\hline Constant & $\begin{array}{l}4.1544^{*} \\
(8.5911)\end{array}$ & $\begin{array}{l}4.0181^{*} \\
(3.8575)\end{array}$ & $\begin{array}{l}5.0536^{*} \\
(3.7612)\end{array}$ \\
\hline \multicolumn{4}{|c|}{ Local market sentiment } \\
\hline STOCKV & $\begin{array}{c}26.4743^{* *} \\
(2.3136)\end{array}$ & & $\begin{array}{c}80.4863^{*} \\
(3.6123)\end{array}$ \\
\hline IFS & $\begin{array}{l}2.8091^{*} \\
(5.6425)\end{array}$ & $\begin{array}{c}1.7265^{*} \\
(8.2369)\end{array}$ & $\begin{array}{l}3.8500^{*} \\
(7.7512)\end{array}$ \\
\hline \multicolumn{4}{|c|}{ Regional market sentiment } \\
\hline EuroCSPREAD & $\begin{array}{l}0.2434 * \\
(6.7736)\end{array}$ & $\begin{array}{l}0.2157^{*} \\
(4.6623)\end{array}$ & $\begin{array}{l}0.3979 * \\
(3.8134)\end{array}$ \\
\hline EuroDEFAULT & & $\begin{array}{l}48.0807 * \\
(4.6402)\end{array}$ & \\
\hline \multicolumn{4}{|c|}{ Global market sentiment } \\
\hline GlobalIFS & $\begin{array}{l}0.3252^{*} \\
(3.5509) \\
\end{array}$ & $\begin{array}{l}0.2942^{*} \\
(3.8815)\end{array}$ & $\begin{array}{l}0.6178^{*} \\
(5.0827)\end{array}$ \\
\hline \multicolumn{4}{|c|}{ Local macrofundamentals } \\
\hline CAC & & $\begin{array}{c}-0.0892 * \\
(4.3947)\end{array}$ & \\
\hline $\bar{U}$ & $\begin{array}{l}0.3325^{*} \\
(8.8743) \\
\end{array}$ & & $\begin{array}{l}1.6152^{*} \\
(9.3625) \\
\end{array}$ \\
\hline GOVDEBT & $\begin{array}{c}0.2261^{*} \\
(22.2359)\end{array}$ & $\begin{array}{l}0.0691 * \\
(9.7908)\end{array}$ & $\begin{array}{c}0.3034^{*} \\
(70.6739)\end{array}$ \\
\hline BANDEBT & $\begin{array}{l}0.0216^{*} \\
(6.1008) \\
\end{array}$ & & $\begin{array}{l}0.0361 * \\
(5.9329) \\
\end{array}$ \\
\hline NFCDEBT & $\begin{array}{l}0.0469^{*} \\
(3.0716)\end{array}$ & $\begin{array}{l}0.0383^{*} \\
(4.9857)\end{array}$ & $\begin{array}{l}0.1994^{*} \\
(5.2636)\end{array}$ \\
\hline \multicolumn{4}{|c|}{ Regional macrofundamentals } \\
\hline EuroCAC & & $\begin{array}{l}-2.4092 * \\
(-3.3623)\end{array}$ & \\
\hline EuroGOVDEBT & $\begin{array}{c}0.1883^{*} \\
(4.8521))\end{array}$ & $\begin{array}{l}0.1723^{*} \\
(2.8677)\end{array}$ & $\begin{array}{l}0.1960^{*} \\
(3.5105)\end{array}$ \\
\hline \multicolumn{4}{|c|}{ Financial linkages } \\
\hline EXTDEBTPUB & $\begin{array}{c}0.1966^{*} \\
(15.8665)\end{array}$ & & $\begin{array}{l}0.1158^{*} \\
(7.0486)\end{array}$ \\
\hline EXTDEBTPRI & $\begin{array}{l}0.0299 * \\
(4.5906)\end{array}$ & & $\begin{array}{l}0.0133^{*} \\
(3.9756)\end{array}$ \\
\hline EXTBEBTBAN & & $\begin{array}{l}0.0061 * \\
(2.6717)\end{array}$ & \\
\hline $\mathrm{R}^{2}$ & 0.8798 & 0.9602 & 0.8945 \\
\hline
\end{tabular}

Notes: FE regression results. In the ordinary brackets below the parameter estimates are the corresponding $z$-statistics, computed using White (1980)'s heteroskedasticity-robust standard errors. In the square brackets below the specification tests are the associated $p$-values. $*, * *$ and $* * *$ indicate significance at $1 \%, 5 \%$, and $10 \%$ respectively. 


\section{Appendix A: Definition of the explanatory variables in the panel regressions and data sources}

A.1. Variables that measure local market sentiment.

\begin{tabular}{|c|c|c|}
\hline Variable & Description & Source \\
\hline $\begin{array}{l}\text { Stock Returns } \\
\text { (STOCKR) }\end{array}$ & $\begin{array}{l}\text { Differences of logged stock index prices of the last and the first } \\
\text { day of the month for each country. }\end{array}$ & Datastream \\
\hline $\begin{array}{l}\text { Stock Volatility } \\
\text { (STOCKV) }\end{array}$ & $\begin{array}{c}\text { Monthly standard deviation of the daily returns of each country's } \\
\text { stock market general index }\end{array}$ & Datastream \\
\hline $\begin{array}{c}\text { Index of Economic Policy Uncertainty } \\
\text { (Germany, France, Italy, and Spain)/(EPU) }\end{array}$ & $\begin{array}{l}\text { This index reflects the frequency of newspaper references to } \\
\text { policy uncertainty and was built by Baker et al., } 2013 \text {. }\end{array}$ & www.policyuncertainty.com \\
\hline $\begin{array}{l}\text { Index of Fiscal stance } \\
\text { (IFS) }\end{array}$ & $\begin{array}{l}\text { This indicator compares a target level of the debt-GDP ratio at a } \\
\text { given point in the future with a forecast based on the government } \\
\text { budget constraint. It was built by Polito and Wickens ( } 2011 \text {, } \\
\text { 2012). Monthly data have been linearly interpolated from yearly } \\
\text { observations for the available data: } 1999-2011\end{array}$ & Provided by the authors. \\
\hline $\begin{array}{l}\text { Consumer Confidence Indicator } \\
\text { (CCI) }\end{array}$ & $\begin{array}{l}\text { This index is built by the European Commission which conducts } \\
\text { regular harmonised surveys of consumers in each country. }\end{array}$ & $\begin{array}{l}\text { European Commission (DG } \\
\text { ECFIN) }\end{array}$ \\
\hline $\begin{array}{l}\text { Rating } \\
\text { (RAT) }\end{array}$ & $\begin{array}{l}\text { Credit rating scale built from Fitch, Moody's, S\&P ratings for } \\
\text { each country. }\end{array}$ & Bloomberg \\
\hline \multicolumn{3}{|c|}{ A.2. Variables that measure regional market sentiment. } \\
\hline Variable & Description & Source \\
\hline $\begin{array}{l}\text { Stock Returns } \\
\text { (EuroSTOCKR) }\end{array}$ & $\begin{array}{l}\text { Differences of logged stock indices (Eurostoxx-50) prices of the } \\
\text { last and the first day of the month for each country. }\end{array}$ & Yahoo-finance \\
\hline $\begin{array}{l}\text { Stock Volatility (VSTOXX) } \\
\text { (EuroSTOCKV) }\end{array}$ & $\begin{array}{c}\text { Eurostoxx-50 implied stock market volatility index. Monthly } \\
\text { average of daily data. }\end{array}$ & www.stoxx.com \\
\hline $\begin{array}{l}\text { Index of Economic Policy Uncertainty } \\
\text { (Europe)/ (EuroEPU) }\end{array}$ & Baker et al., 2013. & www.policyuncertainty.com \\
\hline $\begin{array}{l}\text { Index of the Fiscal stance } \\
(\text { Europe }) /(\text { EuroIFS })\end{array}$ & $\begin{array}{l}\text { Polito and Wickens }(2011,2012) \text {. Monthly data have been linearly } \\
\text { interpolated from yearly observations for the available data: 1999- } \\
2011 \text {. }\end{array}$ & Provided by the authors. \\
\hline $\begin{array}{l}\text { Consumer Confidence Indicator } \\
\text { (Eurozone)/(EuroCCI) }\end{array}$ & European Commission & $\begin{array}{l}\text { European Commission (DG } \\
\text { ECFIN) }\end{array}$ \\
\hline $\begin{array}{l}\text { Credit Spread } \\
\text { (EuroCSPREAD) }\end{array}$ & $\begin{array}{l}\text { Difference between the yields of the iBoxx indices containing } \\
\text { BBB-rated European corporate bonds against the yields of the } \\
\text { respective iBoxx index of AAA-rated European corporate bonds. } \\
\text { Monthly average of daily data. }\end{array}$ & Datastream \\
\hline $\begin{array}{l}\text { ITRAXX } \\
\text { (EuroITRAXX }_{\text {ITRAXX }} \text { ITF }_{\mathrm{NF}} \\
\left.\text { (EuroITRAXX }_{\mathrm{NF}}\right)\end{array}$ & $\begin{array}{l}\text { European 5-year CDS index in the financial and non-financial } \\
\text { sectors: 2010:9-2012:12. } \\
\text { Monthly average of daily data. }\end{array}$ & Bloomberg \\
\hline $\begin{array}{l}\text { EIRVIX-1Y/EIRVIX-10Y } \\
\text { (EuroEIRVIX-1Y) } \\
\text { (EuroEIRVIX-10Y) }\end{array}$ & $\begin{array}{l}\text { 1-year and 10-year interest rate volatility index for the Eurozone } \\
\text { based on the implied volatility quotes of caps (floors). This index } \\
\text { was built by López and Navarro (2013) for the period 2004:1- } \\
\text { 2012:4. }\end{array}$ & Provided by the authors. \\
\hline $\begin{array}{l}\text { Euro Instability } \\
\text { (EuroINSTAB) }\end{array}$ & $\begin{array}{c}\text { Market expectation of the probability that at least one euro area } \\
\text { country will have left the currency union at the end of 2013, built } \\
\text { by Klose and Weigert (2014) for the period 2010:8-2012:8. Monthly } \\
\text { average of daily data. }\end{array}$ & Provided by the authors. \\
\hline $\begin{array}{l}\text { Euro area default risk } \\
\text { (EuroDEFAULT) }\end{array}$ & $\begin{array}{l}\text { Probability of two or more credit events, calculated by Lucas } e t . \text { al. } \\
\qquad(2013): 2008: 1-2012: 12\end{array}$ & Provided by the authors. \\
\hline \multicolumn{3}{|c|}{ A.3. Variables that measure global market sentiment. } \\
\hline Variable & Description & Source \\
\hline $\begin{array}{c}\text { Stock Returns } \\
\text { (GlobalSTOCKR) }\end{array}$ & $\begin{array}{l}\text { Differences of logged stock indices (S\&P 500) prices of the last } \\
\text { and the first day of the month. }\end{array}$ & Datastream \\
\hline $\begin{array}{l}\text { Stock Volatility (VIX) } \\
\text { (GlobalSTOCKV) }\end{array}$ & $\begin{array}{c}\text { Chicago Board Options Exchange Market Volatility Index. } \\
\text { (Implied volatility of S\&P } 500 \text { index options), Monthly average of } \\
\text { daily data. }\end{array}$ & Yahoo-Finance \\
\hline $\begin{array}{c}\text { Index of Economic Policy Uncertainty } \\
\text { (United States) } / \text { (GlobalEPU) }\end{array}$ & Baker et al., 2013. & www.policyuncertainty.com \\
\hline $\begin{array}{l}\text { Index of the Fiscal stance } \\
\text { (United States)/(GlobalIFS) }\end{array}$ & $\begin{array}{l}\text { Polito and Wickens }(2011,2012) \text {. Monthly data have been linearly } \\
\text { interpolated from yearly observations for the available data: 1999- } \\
\qquad 2011\end{array}$ & Provided by the authors. \\
\hline $\begin{array}{l}\text { Global Risk Aversion } \\
\text { (GlobalRISK) }\end{array}$ & $\begin{array}{l}\text { The spread between 10-year fixed interest rates on US swaps and } \\
\text { the yield on 10-year Moody's Seasoned AAA US corporate bonds. } \\
\text { Monthly average of daily data. }\end{array}$ & Datastream \\
\hline $\begin{array}{c}\text { Kansas City Financial Stress Index } \\
\text { (GlobalKCFSI })\end{array}$ & $\begin{array}{l}\text { Based on } 11 \text { financial market variables, each of which captures one } \\
\text { or more key features of financial stress. Built by Hakkio and } \\
\text { Keeton }(2009)\end{array}$ & http://www.kansascityfed.org \\
\hline
\end{tabular}


A.4. Variables that measure local macrofundamentals.

\begin{tabular}{|c|c|c|}
\hline Variable & Description & Source \\
\hline $\begin{array}{l}\text { Net position towards } \\
\text { the rest of the world } \\
\text { (CAC) }\end{array}$ & $\begin{array}{c}\text { Current-account-balance-to-GDP } \\
\text { Monthly data are linearly interpolated from quarterly } \\
\text { observations. }\end{array}$ & OECD \\
\hline $\begin{array}{c}\text { Growth potential } \\
(\mathrm{U})\end{array}$ & Unemployment rate & Eurostat \\
\hline $\begin{array}{l}\text { Competitiveness } \\
\text { (INF) }\end{array}$ & Inflation rate. HICP monthly interannual rate of growth & Eurostat \\
\hline $\begin{array}{l}\text { Fiscal Position } \\
\text { (DEF) } \\
\text { (GOVDEBT) }\end{array}$ & $\begin{array}{c}\text { Government deficit-to-GDP and Government debt-to-GDP. } \\
\text { Monthly data are linearly interpolated from quarterly } \\
\text { observations. }\end{array}$ & Eurostat \\
\hline $\begin{array}{l}\text { Market liquidity } \\
\text { (LIQ) }\end{array}$ & $\begin{array}{c}\text { Domestic Debt Securities. Public Sector Amounts Outstanding } \\
\text { (billions of US dollars) } \\
\text { Monthly data are linearly interpolated from quarterly } \\
\text { observations. }\end{array}$ & $\begin{array}{l}\text { BIS Debt securities statistics. } \\
\text { Table } 18\end{array}$ \\
\hline $\begin{array}{l}\text { Bank's debt } \\
\text { (BANDEBT) }\end{array}$ & $\begin{array}{l}\text { Banks' debt-to-GDP. } \\
\text { Monthly data are linearly interpolated from quarterly observations } \\
\text { for the GDP. }\end{array}$ & $\begin{array}{c}\text { ECB's Monetary Financial } \\
\text { Institutions' balance sheets and } \\
\text { own estimates. } \\
\text { GDP has been obtained from } \\
\text { Eurostat }\end{array}$ \\
\hline $\begin{array}{l}\text { Non-financial corporation's debt } \\
\text { (NFCDEBT) }\end{array}$ & $\begin{array}{l}\text { Non-financial corporations' debt-to-GDP. } \\
\text { Monthly data are linearly interpolated from quarterly observations } \\
\text { for the GDP. }\end{array}$ & $\begin{array}{c}\text { ECB's Monetary Financial } \\
\text { Institutions' balance sheets and } \\
\text { own estimates. } \\
\text { GDP has been obtained from } \\
\text { Eurostat }\end{array}$ \\
\hline $\begin{array}{l}\text { Household's debt } \\
\text { (HOUDEBT) }\end{array}$ & $\begin{array}{l}\text { Households' debt-to-GDP of country. } \\
\text { Monthly data are linearly interpolated from quarterly observations } \\
\text { for the GDP. }\end{array}$ & $\begin{array}{c}\text { ECB's Monetary Financial } \\
\text { Institutions' balance sheets and } \\
\text { own estimates. } \\
\text { GDP has been obtained from } \\
\text { Eurostat }\end{array}$ \\
\hline \multicolumn{3}{|c|}{ A.5. Variables that measure regional macrofundamentals. } \\
\hline Variable & Description & Source \\
\hline $\begin{array}{l}\text { Net position towards } \\
\text { The rest of the world. } \\
\text { (EuroCAC) }\end{array}$ & $\begin{array}{c}\text { Current-account-balance-to-GDP } \\
\text { Monthly data are linearly interpolated from quarterly } \\
\text { observations. }\end{array}$ & OECD \\
\hline $\begin{array}{l}\text { Growth potential } \\
\text { (EuroU) }\end{array}$ & Unemployment rate & Eurostat \\
\hline $\begin{array}{l}\text { Competitiveness } \\
\text { (EuroINF) }\end{array}$ & Inflation rate. HICP monthly interannual rate of growth & Eurostat \\
\hline $\begin{array}{l}\text { Fiscal Position } \\
\text { (EuroDEF) } \\
\text { (EuroGOVDEBT) }\end{array}$ & $\begin{array}{c}\text { Government deficit-to-GDP and Government debt-to-GDP. } \\
\text { Monthly data are linearly interpolated from quarterly } \\
\text { observations. }\end{array}$ & Eurostat \\
\hline $\begin{array}{l}\text { Market liquidity } \\
\text { (EuroLIQ) }\end{array}$ & $\begin{array}{c}\text { Domestic Debt Securities. Public Sector Amounts Outstanding } \\
\text { (billions of US dollars) } \\
\text { Monthly data are linearly interpolated from quarterly } \\
\text { observations. }\end{array}$ & $\begin{array}{l}\text { BIS Debt securities statistics. } \\
\text { Table } 18\end{array}$ \\
\hline \multicolumn{3}{|c|}{ A.6. Variables that measure financial linkages. } \\
\hline Variable & Description & Source \\
\hline $\begin{array}{l}\text { Foreign claims on bank's debt } \\
\text { (EXTDEBTBAN) }\end{array}$ & $\begin{array}{c}\text { Foreign bank claims on banks debt-to-GDP. } \\
\text { Monthly data are linearly interpolated from quarterly } \\
\text { observations. }\end{array}$ & $\begin{array}{l}\text { BIS Consolidated banking } \\
\text { statistics. Table 9C. GDP has } \\
\text { been obtained from the } \\
\text { OECD. }\end{array}$ \\
\hline $\begin{array}{l}\text { Foreign claims on public's debt } \\
\text { (EXTDEBTPUB) }\end{array}$ & $\begin{array}{c}\text { Foreign bank claims on government debt-to-GDP. } \\
\text { Monthly data are linearly interpolated from quarterly } \\
\text { observations. }\end{array}$ & $\begin{array}{l}\text { BIS Consolidated banking } \\
\text { statistics. Table 9C. GDP has } \\
\text { been obtained from the } \\
\text { OECD }\end{array}$ \\
\hline $\begin{array}{l}\text { Foreign claims on non-financial private's debt. } \\
\text { (EXTDEBTPRI) }\end{array}$ & $\begin{array}{c}\text { Foreign bank claims on non-financial private debt-to-GDP. } \\
\text { Monthly data are linearly interpolated from quarterly } \\
\text { observations. }\end{array}$ & $\begin{array}{l}\text { BIS Consolidated banking } \\
\text { statistics. Table 9C. GDP has } \\
\text { been obtained from the } \\
\text { OECD. }\end{array}$ \\
\hline $\begin{array}{l}\text { Cross-border banking linkages } \\
\text { (XXYYBAN) }\end{array}$ & $\begin{array}{l}\text { Percentage of the total foreign claims on country XX held by } \\
\text { country YY's banks }\end{array}$ & $\begin{array}{l}\text { BIS Consolidated banking } \\
\text { statistics. Table 9D and own } \\
\text { estimates. }\end{array}$ \\
\hline
\end{tabular}


Supplementary Material
Click here to download Supplementary Material: Acknowledgements and Vitae.docx 